\title{
An X-Ray Study of the System Uranium Monocarbide- Uranium Dicarbide-Beryllium Carbide
}

\author{
M. D. Burdick, H. S. Parker, R. S. Roth, and E. L. McGandy
}

\begin{abstract}
Mixed carbide preparations within the system uranium monocarbide-uranium dicarbideberyllium carbide were investigated after heating and quenching. X-ray diffraction methods were used to identify the phases found and to determine the degree of interaction. Carbide alloys were studied after treatments at $1,700^{\circ}$ and $1,900^{\circ} \mathrm{C}$, and a constitutional diagram for the $1,700^{\circ} \mathrm{C}$ level is presented. No ternary compounds were identified within the system. The limit of solubility of beryllium carbide in uranium monocarbide at $1,700^{\circ}$ and $1,900^{\circ} \mathrm{C}$ was found to be 20 mole percent and 40 mole percent, respectively. Lattice parameters based on X-ray patterns in the back-reflection region failed to indicate any other interactions, but evidence is presented to indicate some solid solution among the uranium carbides without lattice parameter change. The room-temperature stability of uranium sesquicarbide $\left(\mathrm{U}_{2} \mathrm{C}_{3}\right)$, which has been reported by other investigators, was verified. X-ray diffraction data were obtained for this cubic compound, using $\mathrm{CuK}_{\alpha}$ radiation.
\end{abstract}

\section{Introduction}

Uranium, as a metal and in the form of various compounds, is the usual source of energy in nuclear reactors. As a moderator and structural material for piles operating at temperatures above the useful range for metals, some form of beryllium is among the foremost of the ceramic materials considered because of favorable cross-sectional properties and high thermal conductivity. For applications other than reactors, the carbides of these elements have been investigated and have been found to be suitable for special high-temperature applications, for example, crucibles.

An uranium carbide, later shown to have been $\mathrm{UC}_{2}$, was prepared by Moissan [1] ${ }^{1}$ in 1896 . Other workers $[2,3,4,5,6,7,8,9,10,11]$ established the structure and determined some of the properties of the three uranium carbides, $\mathrm{UC}, \mathrm{U}_{2} \mathrm{C}_{3}$, and $\mathrm{UC}_{2}$. Beryllium carbide, discovered in 1895 by Lebeau [12], remained almost a laboratory oddity until recently. Stackelberg and Quatrum [13] in 1934 published the crystallographic structure of $\mathrm{Be}_{2} \mathrm{C}$, and Kielland and Tronstad [14] found it served a useful purpose as an intermediate product in the production of beryllium chloride. Beryllium carbide was little used as a refractory because other materials were available, which were more stable with respect to air and moisture and were less toxic.

In nuclear reactors, temperatures must be maintained at the highest possible levels for good efficiency. The materials used in the construction of reactors must, therefore, be stable at the temperatures involved, and, in addition, must be compatible with each other. The favorable nuclear properties of the uranium carbides and beryllium carbide made desirable an investigation of combinations of these materials. The present study was undertaken to determine the constitution of alloys resulting from solid-state reaction within the system $\mathrm{UC}-\mathrm{UC}_{2}-\mathrm{Be}_{2} \mathrm{C}$.

\footnotetext{
i Figures in brackets indicate the literature references at the end of this paper.
}

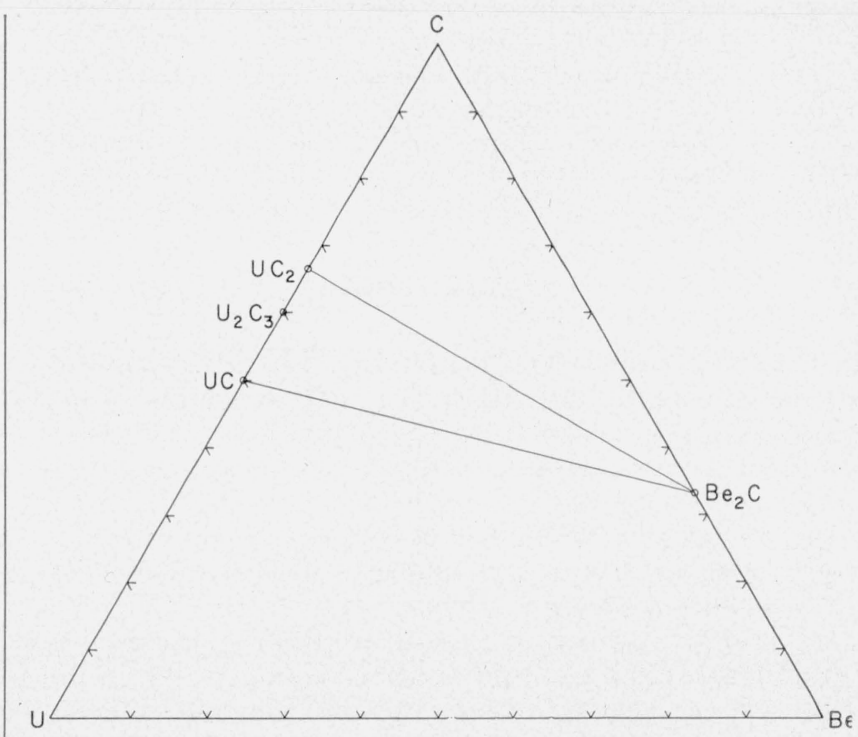

Figure 1. Relation of the end members of the system $\mathrm{UC}^{-\mathrm{UC}_{2}-\mathrm{Be}} \mathrm{C}$ to that of the constituent elements, in mole percent.

Figure 1 shows the relation of the end members of this system to that of the constituent elements (U, $\mathrm{Be}$, and $\mathrm{C}$ ).

\section{Materials}

The uranium-carbon alloys used in this study were supplied by Battelle Memorial Institute. They were prepared by melting the materials in an induction furnace and remelting in argon in an arc furnace. The uncombined carbon of the arc-melted alloys was usually not over 0.03 percent by weight. The chemical compositions of the starting materials are given in table 1 . The uranium-carbon alloys, designated by $\mathrm{A}$ following the alloy number in table 1 , were made available for this study by M. W. Mallett et al. [9,11] after the completion of work 
TABLE 1. Chemical composition of materials

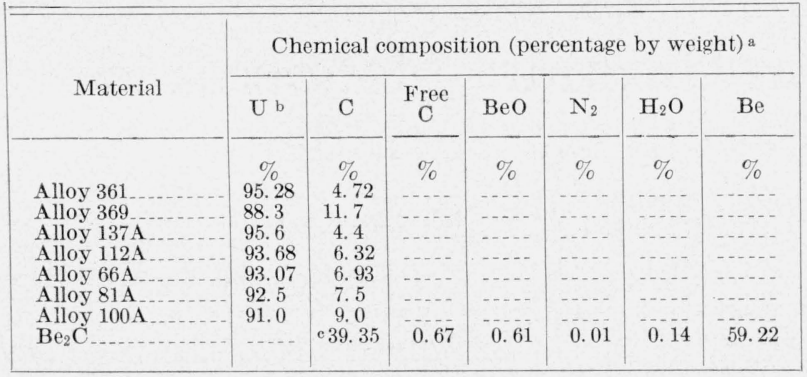

\& The uranium-carbon alloys were supplied and analyzed by Batelle Memorial Institute. The beryllium carbide was supplied and analyzed by Brush Beryllium Co.

b Uranium by difference.

c Carbon by difference.

on the uranium-carbon system. Alloys 361 and 369 were freshly prepared for this study, after it was found that the older alloys had "aged" and no longer gave reproducible results. The data in this report were obtained on mixtures of alloys 361 , 369 , and beryllium carbide.

The beryllium carbide was of 98.3-percent purity, which was the highest quality available at the time of its purchase. The impurities were beryllia $(\mathrm{BeO})$, carbon, beryllium nitride $\left(\mathrm{Be}_{3} \mathrm{~N}_{2}\right)$, and moisture.

\section{Equipment}

Figure 2 shows the inductively heated quenching furnace used for all heat treatments in this study. The base of the furnace consists of a 12-in. cube made of $1 / 4$-in. steel plate with all-welded construction. A fused-silica tube, with a 5 -in. inside diameter, is set in a groove in the top of the base, and a vacuumtight seal is obtained by means of a neoprene "O" gasket and a clamping ring. The furnace head is attached to the top of the silica tube by means of a similar arrangement and is water-cooled. An induction coil, consisting of eight turns, is placed concentric with and midway along the silica tube.

The prism and window on the furnace head provide a means for temperature measurement and observation of specimens with an optical pyrometer mounted in a horizontal position. A neoprene "O" gasket forms a vacuum-tight seal between the tempered glass window and the furnace head. The optical pyrometer was calibrated with the window and prism in the line of sight by the Temperature Measurement Section of the National Bureau of Standards. A Kovar insulated terminal is soldered in place through the head to act as a fuse-wire support and electrode for the quenching current. The head itself serves as the other electrode.

The susceptor and other structural parts of the furnace were machined from suitable carbon shapes. The susceptor assembly is mounted concentric with the silica tube at its midpoint, and the assembly is supported by a carbon pipe 1/2-in. outside diameter by 1 -in. inside diameter, which extends to a hole in the top of the furnace base. The pipe also

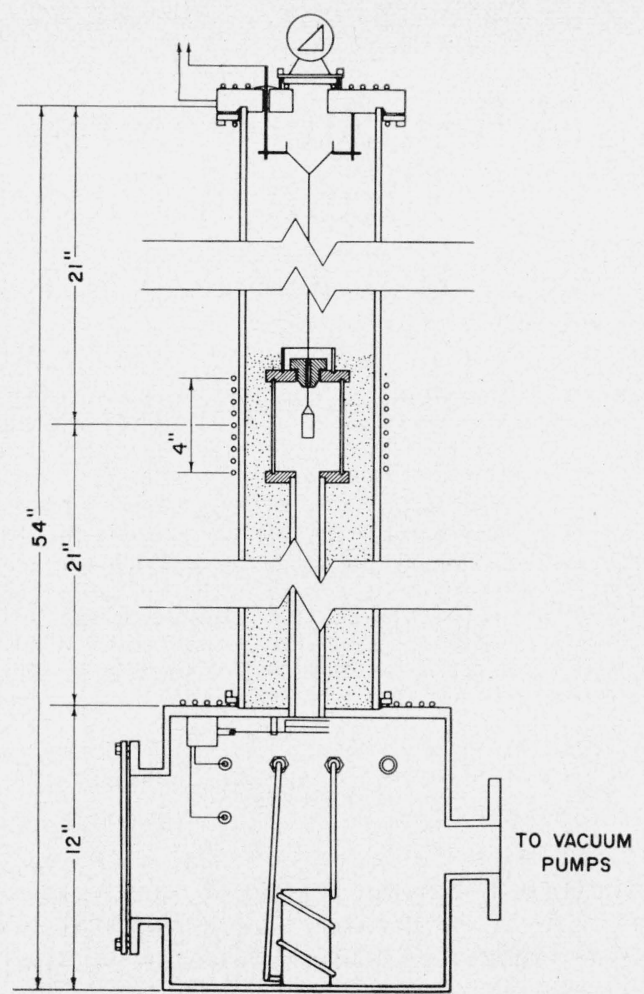

FIgURE 2. Schematic drawing of an inductively heated furnace used for heating and quenching carbide alloys in controlled atmospheres.

serves as a guide to direct the specimen to the quench cup and to retain the thermal insulation. The entire space above the furnace base around the pipe and susceptor assembly is solidly packed with carbon-black insulation to approximately $1 / 4$ in. below the upper rim of the stack on top of the susceptor assembly. Twelve to 14 deep holes, formed in the carbon black with a $1 / 8$-in. rod, aid in the escape of adsorbed gases during evacuation and heating.

Within the furnace base, a solenoid-operated shutter assembly serves as a radiation sbield under the lower end of the carbon pipe. Electricity is brought into the base by means of two Kovar insulated terminals soldered through the side wall. The cup, containing about $750 \mathrm{ml}$ of a quenching oil, is a thin-walled brass tube closed at the lower end. Because of the small heat capacity of the cup and the necessity for as rapid cooling as possible, a water-cooling jacket of $1 / 4-i n$. copper tubing was placed around the cup. The water inlet and outlet, as well as the atmosphere inlet, consists of $1 / 4-i n$. pipe nipples welded through the sidewall of the furnace base. Access to the interior of the furnace base is obtained by a 6-in. pipe flange welded to one side of the base. The flange is provided with a cover plate and rubber gasket. A standard 2-in. pipe flange welded to the opposite side of the furnace base permits connection to the vacuum system.

Specimen holders used with the furnace consist of two general types: (1) refractory metal holders sus- 
pended from the furnace head, when specimens are to be quenched, and (2) carbon or graphite crucibles, when specimens are to be cooled in the furnace. When specimens are to be quenched, the sample cup consists of a hollow cylinder, $5 / 8$-in. in diameter and 1 in. tall, with a removable bottom. The entire assembly is shaped from 0.010-in. molybdenum. A bail of 0.025 -in. molybdenum wire is provided. The cylinder containing the specimen is suspended from a 0.010 -in. molybdenum wire attached to a platinum fuse wire strung between two supports on the furnace head. The molybdenum support wire extends through the $3 / 16$-in. sight hole in the susceptor cover plug. In cases where it is not necessary to quench the specimen, and a refractory metal holder is desired, the platinum fuse wire and the 0.010-in. molybdenum support wire are replaced with a 0.040-in. molybdenum wire. The second type of specimen holder used in the furnace is fabricated from graphite or carbon rods. This holder is a hollow cylindrical crucible with an external flange to support it from the susceptor cover to allow the main body of the crucible to extend well into the hot zone of the furnace.

Before heating any specimens in the furnace, the parts were outgassed by heating the furnace to $2,000^{\circ}$ to $2,100^{\circ} \mathrm{C}$ in vacuum. When not in use, the furnace was continuously pumped by a small auxiliary mechanical pump to maintain a pressure of approximately $50 \mu$ of mercury in the chamber at all times. If, however, the furnace was not to be used for an extended period, it was evacuated and filled with helium or argon. If the furnace had been maintained under reduced pressure, either during a heating period or during an idle period, it was always filled with helium or argon before exposing the interior to the air. This procedure minimized the adsorption of air on the carbon susceptor and on the carbon-black insulation. A motor-generator, rated at $75 \mathrm{kw}$ at $9,600 \mathrm{cps}$, supplied power to the furnace. About 10 to $12 \mathrm{~min}$. were required to reach a temperature of $1,900^{\circ} \mathrm{C}$, and about $3 \mathrm{kw}$ were required to maintain the temperature at that level. The specimen temperature was easily controlled to within \pm 5 deg $\mathrm{C}$ by making small manual adjustments of the field excitation of the generator.

X-ray diffraction patterns were obtained with a high-angle goniometer spectrometer, using $\mathrm{Cu} \mathrm{K}_{\alpha}$ radiation. The diffracted X-ray intensities were recorded on a strip chart on which 1 in. was equivalent to $1 \mathrm{deg} 2 \theta$.

\section{Methods}

\subsection{Preparation and Treatment of Alloys}

The starting materials from wbich the preparations were compounded (see table 1) were obtained in two conditions. The uranium-carbon alloys were received in ingot form. The ingots were coarsely crushed in a "diamond" mortar, and were further reduced in a boron carbide mortar to pass a No. 325 U. S. Standard Sieve. These operations were per- formed in a dry box in an atmosphere of carbon dioxide. The beryllium carbide was obtained in powdered form that passed a No. 325 U. S. Standard Sieve.

Five-gram batches of the appropriate amounts of the various starting materials were weighed on an analytical balance. The powdered materials were blended by grinding together in a boron carbide mortar, within a dry box, prior to pressing. Specimens for solid-state reaction were pressed in hardened steel molds into pellet form, usually $3 / 8$-in. diameter and approximately $3 / 8$ to $1 / 2$ in. high. The specimens were placed in graphite cups within the molybdenum cup, so that contamination due to heating in contact with molybdenum was avoided. After the furnace was assembled, with specimens in place, the chamber was "pumped down" to a pressure of $1 \mu$ of mercury and then filled with argon. The pumping and refilling with argon was repeated once before heating was started. After a $2-\mathrm{hr}$ heat treatment at the elevated temperature (either $1,700^{\circ}$ or $1,900^{\circ} \mathrm{C}$ ), the specimen assembly was cooled rapidly by dropping it into the cold oil. The quenching oil was removed from the specimens by soaking them overnight in carbon tetrachloride. The cleaned, dry pellets were crushed and ground in a boron carbide mortar within the dry box, to pass a No. 200 U. S. Standard Sieve. The fine powders were stored in a desiccator, usually not longer than 3 days, before they were subjected to X-ray analysis.

The results obtained for the constitution of mixed carbides within the system $\mathrm{UC}-\mathrm{UC}_{2}-\mathrm{Be}_{2} \mathrm{C}$, after the treatment described above, are based on roomtemperature X-ray analyses of the quenched crystalline phases and on the lattice parameters.

A uniform period of $2 \mathrm{hr}$ at the elevated temperature was selected, based on a series of experiments on alloy preparations involving solid-state reactions between mixtures of $\mathrm{UC}$ and $\mathrm{Be}_{2} \mathrm{C}$. The degree of reaction, as indicated by the unit-cell size of the resulting solid solutions, was evaluated after total reaction times of 2,4 , and $6 \mathrm{hr}$, with grinding and repressing between heat treatments. It is reasonable to assume that a 6 -hr total reaction time with intermediate grinding and repressing at 2 -hr intervals is more conducive to the attainment of equilibrium than is a single 6-hr treatment. No significant differences in lattice parameters of the UC solid solutions were observed between the alloys heated for 2,4 , or $6 \mathrm{hr}$. The shortest of these reaction periods was selected for convenience and to minimize compositional changes, such as carbon "pickup" and beryllium loss due to dissociation of the beryllium carbide.

\subsection{X-Ray Methods}

The lattice parameters for cubic compounds and solid solutions were evaluated by taking the average of the values obtained from the last five diffraction peaks in the back-reflection region of the X-ray pattern. The parameters of the tetragonal $\mathrm{UC}_{2}$ compound and solid solutions were evaluated by taking the average of the values obtained from those 
reflections that had the greatest contribution to the desired parameter. The " $a$ " parameter was found by taking the average of the values obtained from the $(h k 0)$ reflections $(200),(220),(310),(400)$, and (330), and the "c" parameter was found by appropriate calculations, using the formula

$$
\frac{l^{2}}{c^{2}}=\frac{1}{d^{2}}-\frac{h^{2}+k^{2}}{a^{2}}
$$

for the diffraction reflections (103), (004), (114), (204), (105), (215), (116), (206), (305), and (107).

\subsection{Chemical Methods and Precision}

Early in the investigation, it was believed that chemical analysis of the alloys after heat treatment would prove of value in interpreting the results of the X-ray analyses and in more accurately locating the phase boundaries that exist in the system $\mathrm{UC}-\mathrm{UC}_{2}-\mathrm{Be}_{2} \mathrm{C}$. The varying degrees of instability of the uranium-carbon alloys and of beryllium carbide, with respect to air and moisture, made it desirable to analyze preparations as soon as possible after heat treatment. Unfortunately, analytical procedures for the separation and analysis of uranium, beryllium, and carbon, in the form of mixed carbides, were not available. It was necessary to develop new techniques and adapt other techniques for use in this study.

The methods that are described for the separation and analysis of uranium, beryllium, and carbon are not intended to represent a completely developed, standard method of analysis, but are presented as a guide to other workers.

Some of the powdered, quenched preparations that were analyzed by X-ray methods were analyzed chemically for uranium, beryllium, iron, and carbon as follows:

\section{a. Uranium}

Duplicate samples of approximately $0.50 \mathrm{~g}$ were weighed into $125-\mathrm{ml}$ Erlenmeyer flasks. Nitric and perchloric acids were added, and the sample was digested for $2 \mathrm{hr}$ on a hot plate. When solution of the sample was complete, a second portion of nitric acid was added.

The solution was then transferred to a special continuous extractor, similar in design to the one described by Rodden and Warf [15], except that a Friedrichs condenser was used without an extension tube. The solution was extracted for $1 \frac{1}{2} \mathrm{hr}$ with diethyl ether, at the end of which time the uranium had been quantitatively transferred to the boiler flask. The aqueous layer remaining in the extractor tube contained ammonium nitrate, beryllium, and any iron that might have been present as an impurity.

After evaporation of the ether, the uranium extract was fumed with sulfuric acid to remove any organic matter. The solution was then diluted, and the uranium was precipitated as ammonium diuranate with carbonate-free ammonium hydroxide solution. The precipitate was filtered on Whatman No. 42 filter paper, drained, and ignited in a platinum crucible at $1,000^{\circ} \mathrm{C}$ for $1 \mathrm{hr}$. The ignited precipitate was cooled and weighed as $\mathrm{U}_{3} \mathrm{O}_{8}$.

\section{b. Beryllium}

The aqueous layer remaining after the extraction was transferred to a beaker, evaporated to dryness, and the ammonium nitrate volatilized by the method of J. Lawrence Smith [16]. Beryllium was determined by one of two methods. If more than 2 percent by weight was indicated by the nominal composition of the sample, a gravimetric method was used, but if less was indicated, a fluorimetric method was used.

For the gravimetric determination of beryllium, the solution remaining after the ammonium nitrate volatilization was diluted, and the beryllium was precipitated with ammonium hydroxide as the hydrous oxide. The precipitate was filtered on a Whatman No. $41 \mathrm{H}$ filter paper, drained, and ignited in a platinum crucible at $1,000^{\circ} \mathrm{C}$ for $1 \mathrm{hr}$. The ignited precipitate was cooled and weighed as $\mathrm{BeO}$.

For the fluorimetric determination of beryllium, the solution from the ammonium nitrate volatilization was diluted in a volumetric flask, and suitable aliquots were transferred to $50-\mathrm{ml}$ volumetric flasks. These aliquots were treated according to the method of Fletcher, White, and Sheftel [17], and the fluorescence of the resulting solutions was compared with that of fluorescent uranium glass standards in a photoelectric fluorimeter designed and built at the Bureau by E. L. McGandy.

$$
\text { c. Iron }
$$

Iron was present in small quantities in all the alloys tested. No sample was found that contained more than 0.35 nor less than 0.10 percent of iron. Approximately, one in every three samples was tested for iron. For this determination, an aliquot was removed from the solution after ammonium nitrate volatilization and transferred to a $25-\mathrm{ml}$ volumetric flask. This was treated according to a standard method described by Sandell [18], using orthophenanthroline as a colorimetric reagent. The optical density of the resulting solution was compared with that of standard solutions in a Beckman model B spectrophotometer.

\section{d. Carbon}

The carbon content of samples containing no beryllium was determined by ignition in porcelain boats in an oxygen train at $1,000^{\circ} \mathrm{C}$. It was found, however, that this temperature was too low to completely decompose the samples containing beryllium carbide. Samples containing beryllium carbide were decomposed at higher temperatures, obtained in a modified inductively-heated combustion furnace, with the aid of a special flux containing copper as a combustion catalyst. In the determination of small amounts of carbon in beryllium metal, J. J. Tregonning [19] described the use of copper as a combustion catalyst. 
A special flux, consisting of $0.80 \mathrm{~g}$ of open-hearth iron (NBS Standard Sample 55) and $0.90 \mathrm{~g}$ of powdered copper, was added to a combustion crucible. About $0.20 \mathrm{~g}$ of the carbide was then accurately weighed in the crucible, and the mixture was blended, placed in the inductively heated combustion furnace, and burned in a stream of purified oxygen. The carbon dioxide formed was absorbed in ascarite contained in a Nesbitt bulb.

Because the samples could not be dried at $110^{\circ} \mathrm{C}$ without some oxidation taking place, several of them were checked for moisture content by a special procedure. For this purpose, a crucible, $15 \mathrm{~mm}$ in diameter, $15 \mathrm{~mm}$ high, and having a $2-\mathrm{mm}$ wall thickness, was machined from graphite. About 0.20 $\mathrm{g}$ of sample was weighed accurately into the crucible, and placed in the inductively heated combustion furnace. The sample was heated at approximately $1,200^{\circ} \mathrm{C}$ in a stream of dried helium, and the evolved moisture was absorbed in magnesium perchlorate contained in a Nesbitt bulb.

The standard deviation of an individual analysis, as well as the estimated precision that might be obtained when 2 or 3 determinations are made, is given in table 2. These data were derived from the uranium, beryllium, and carbon analyses made of the mixed carbide alloys. The lack of standard samples of these mixed carbides and the time limitation imposed by the expiration of the investigation prevented the accumulation of sufficient data to justify any definite statements concerning the accuracy of the analytical methods.

The results of analyses of various preparations in the system $\mathrm{UC}-\mathrm{UC}_{2}-\mathrm{Be}_{2} \mathrm{C}$ are given in table 3 . The data were selected as being typical of the results obtained, as well as indicating the compositional range over which the various elements occurred in the alloys. The nominal composition was included in the table to show that the analyzed compositions were in reasonably good agreement with the intended compositions. The uranium and beryllium percentages are the average of duplicate determinations, and the carbon values represent the average of three determinations. The sum of the percentages of the constituent elements found is less than 100 percent in every case. The departure from 100 percent is found, in general, to increase with increasing amounts of beryllium carbide in the alloy. In most instances smaller departures from 100 percent were found for the alloys heat-treated at $1,900^{\circ} \mathrm{C}$ than for the alloys heat-treated at $1,700^{\circ} \mathrm{C}$. The results have been corrected for the small amount (less than $2 \%$ by weight) of moisture found and are expressed on the basis of the dry material. The

TABLE 2. Estimated standard deviation and precision of analytical methods

\begin{tabular}{|c|c|c|c|c|c|c|}
\hline \multirow{2}{*}{ Element } & \multirow{2}{*}{$\begin{array}{c}\text { Composi- } \\
\text { tional } \\
\text { range } \\
\text { (\% by } \\
\text { weight) }\end{array}$} & \multirow{2}{*}{$\begin{array}{l}\text { Method of } \\
\text { analysis }\end{array}$} & \multirow{2}{*}{$\begin{array}{l}\text { Degrees } \\
\text { of free- } \\
\text { dom on } \\
\text { which } \\
\text { standard } \\
\text { deviation } \\
\text { is based a }\end{array}$} & \multirow{2}{*}{$\begin{array}{c}\text { Esti- } \\
\text { mated } \\
\text { standard } \\
\text { deviation } \\
\text { of an } \\
\text { indi- } \\
\text { vidual } \\
\text { analysis b }\end{array}$} & \multicolumn{2}{|c|}{$\begin{array}{l}\text { Estimated standard } \\
\text { deviation of aver- } \\
\text { age e for- }\end{array}$} \\
\hline & & & & & $n=2$ & $n=3$ \\
\hline $\begin{array}{l}\mathrm{U} \ldots \ldots \\
\mathrm{Be} \ldots \ldots \\
\mathrm{Be} \ldots \ldots \\
\mathrm{C} \ldots \ldots\end{array}$ & $\begin{array}{r}55 \text { to } 95 \\
0 \text { to } 2 \\
2 \text { to } 12 \\
4 \text { to } 12\end{array}$ & $\begin{array}{l}\text { Gravimetric } \\
\text { Fluorimetric.- } \\
\text { Gravimetric.-- } \\
\text { Combustion -- }\end{array}$ & $\begin{array}{r}53 \\
22 \\
34 \\
146\end{array}$ & $\begin{array}{l}0.34 \\
.036 \\
.21 \\
.088\end{array}$ & $\begin{array}{l}0.24 \\
.025 \\
.15 \\
.062\end{array}$ & $\begin{array}{l}0.20 \\
.021 \\
.12 \\
.051\end{array}$ \\
\hline
\end{tabular}

a See [21] for definition of statistical terms and description of methods.

b Standard deviation of an individual analysis $=\sqrt{(\text { sum of squares }) /(\text { degrees of }}$ freedom).

- Standard deviation of average $=($ standard deviation of individual analysis $) /$ $\sqrt{\text { (number of determinations). }}$

TABLE 3. Typical analyses of alloys within the system $\mathrm{UC}-\mathrm{UC}_{2}-\mathrm{Be}_{2} \mathrm{C}$

\begin{tabular}{|c|c|c|c|c|c|c|c|c|c|c|c|}
\hline \multirow{3}{*}{ Alloy } & \multirow{3}{*}{$\begin{array}{c}\text { Tempera- } \\
\text { ture of } \\
\text { heat treat- } \\
\text { ment }\end{array}$} & \multicolumn{6}{|c|}{ Nominal composition } & \multirow{2}{*}{\multicolumn{4}{|c|}{$\begin{array}{l}\text { Analyzed composition }{ }^{a} \text { (percentage by } \\
\text { weight) }\end{array}$}} \\
\hline & & \multicolumn{3}{|c|}{ Mole percent } & \multicolumn{3}{|c|}{ Percentage by weight } & & & & \\
\hline & & $\mathrm{UC}$ & $\mathrm{UC}_{2}$ & $\mathrm{Be}_{2} \mathrm{C}$ & $\mathrm{U}$ & $\mathrm{Be}$ & $\mathrm{C}$ & $\mathrm{U}$ & $\mathrm{Be}^{\mathrm{b}}$ & $\mathrm{C}$ & Total \\
\hline $\begin{array}{l}85 \\
85 \\
187 \\
187 \\
150 \\
101 \\
101\end{array}$ & $\begin{array}{l}{ }^{\circ} C \\
1,700 \\
1,900 \\
1,700 \\
1,900 \\
1,700 \\
1,900 \\
1,700 \\
1,900\end{array}$ & $\begin{array}{l}92 \\
92 \\
80 \\
80 \\
21.7 \\
21.7 \\
10 \\
10\end{array}$ & $\begin{array}{l}8 \\
8 \\
20 \\
20 \\
78.3 \\
78.3 \\
90 \\
90\end{array}$ & 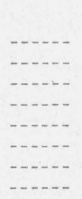 & $\begin{array}{l}94.83 \\
94.83 \\
94.29 \\
94.29 \\
91.17 \\
91.17 \\
91.25 \\
91.25\end{array}$ & $\begin{array}{l}\cdots+\cdots \\
\cdots \\
\cdots\end{array}$ & $\begin{array}{l}5.17 \\
5.17 \\
5.71 \\
5.71 \\
8.83 \\
8.83 \\
8.75 \\
8.75\end{array}$ & $\begin{array}{l}93.4 \\
93.9 \\
93.8 \\
93.8 \\
91.7 \\
91.2 \\
89.6 \\
91.0\end{array}$ &  & $\begin{array}{l}\text { 4. } 85 \\
\text { 5. } 18 \\
\text { 5. } 64 \\
\text { 5. } 52 \\
\text { 7. } 90 \\
\text { 7. } 99 \\
\text { 8. } 37 \\
\text { 8. } 50\end{array}$ & $\begin{array}{l}98.2 \\
99.1 \\
99.4 \\
99.3 \\
99.6 \\
99.2 \\
98.0 \\
99.5\end{array}$ \\
\hline $\begin{array}{l}118 \\
118 \\
181 \\
181\end{array}$ & $\begin{array}{l}1,700 \\
1,900 \\
1,700 \\
1,900\end{array}$ & $\begin{array}{l}65 \\
65 \\
35 \\
35\end{array}$ & $\begin{array}{l}25 \\
25 \\
55 \\
55\end{array}$ & $\begin{array}{l}10 \\
10 \\
10 \\
10\end{array}$ & $\begin{array}{l}92.72 \\
92.72 \\
91.30 \\
91.30\end{array}$ & $\begin{array}{r}0.78 \\
.78 \\
.77 \\
.77\end{array}$ & $\begin{array}{l}5.97 \\
5.97 \\
7.93 \\
7.93\end{array}$ & $\begin{array}{l}92.2 \\
91.4 \\
90.1 \\
90.6\end{array}$ & $\begin{array}{r}0.84 \\
.64 \\
.59 \\
.64\end{array}$ & $\begin{array}{l}\text { 6. } 37 \\
\text { 6. } 33 \\
\text { 8. } 00 \\
8.10\end{array}$ & $\begin{array}{l}99.4 \\
98.4 \\
98.7 \\
99.3\end{array}$ \\
\hline $\begin{array}{l}91 \\
91 \\
92 \\
92 \\
93 \\
93 \\
98 \\
98\end{array}$ & $\begin{array}{l}1,700 \\
1,900 \\
1,700 \\
1,900 \\
1,700 \\
1,900 \\
1,700 \\
1,900\end{array}$ & $\begin{array}{l}50 \\
50 \\
45 \\
45 \\
40 \\
40 \\
15 \\
15\end{array}$ & $\begin{array}{l}10 \\
10 \\
15 \\
15 \\
20 \\
20 \\
45 \\
45\end{array}$ & $\begin{array}{l}40 \\
40 \\
40 \\
40 \\
40 \\
40 \\
40 \\
40\end{array}$ & $\begin{array}{l}87.49 \\
87.49 \\
87.17 \\
87.17 \\
86.85 \\
86.85 \\
85.29 \\
85.29\end{array}$ & $\begin{array}{l}\text { 4. } 42 \\
4.42 \\
4.40 \\
4.40 \\
4.39 \\
4.39 \\
4.31 \\
4.31\end{array}$ & $\begin{array}{r}8.09 \\
8.09 \\
8.43 \\
8.43 \\
8.76 \\
8.76 \\
10.40 \\
10.40\end{array}$ & $\begin{array}{l}83.6 \\
85.6 \\
83.6 \\
85.9 \\
81.8 \\
84.5 \\
81.0 \\
83.6\end{array}$ & $\begin{array}{l}\text { 4. } 44 \\
\text { 4. } 41 \\
\text { 3. } 97 \\
\text { 3. } 99 \\
\text { 4. } 14 \\
\text { 4. } 46 \\
\text { 3. } 87 \\
\text { 3. } 98\end{array}$ & $\begin{array}{r}7.61 \\
8.09 \\
7.11 \\
8.61 \\
7.52 \\
8.72 \\
9.69 \\
10.1\end{array}$ & $\begin{array}{l}95.6 \\
98.1 \\
94.7 \\
98.5 \\
93.5 \\
97.8 \\
94.6 \\
97.8\end{array}$ \\
\hline 108 & $\begin{array}{l}1,700 \\
1,700 \\
1,700\end{array}$ & $\begin{array}{l}25 \\
20 \\
10\end{array}$ & $\begin{array}{r}5 \\
10 \\
20\end{array}$ & $\begin{array}{l}70 \\
70 \\
70\end{array}$ & $\begin{array}{l}73.89 \\
73.43 \\
72.54\end{array}$ & $\begin{array}{l}13.06 \\
12.98 \\
12.82\end{array}$ & $\begin{array}{l}13.05 \\
13.58 \\
14.64\end{array}$ & $\begin{array}{l}71.0 \\
69.6 \\
67.4\end{array}$ & $\begin{array}{l}10.6 \\
10.7 \\
11.9\end{array}$ & $\begin{array}{l}11.1 \\
11.5 \\
13.7\end{array}$ & $\begin{array}{l}92.7 \\
91.8 \\
93.0\end{array}$ \\
\hline
\end{tabular}

a The uranium and beryllium values are the average of two determinations; the carbon values are the average of three determinations.

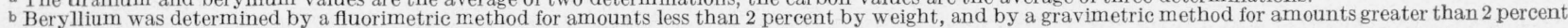
by weight. 
percentage of iron, in those specimens which were analyzed for iron content, was found to be too low (less than $0.35 \%$ by weight) to account for the departure from 100 percent.

Both the uranium carbides [1] and beryllium carbide are known to be unstable in the presence of air and moisture. The alloys heat-treated at $1,700^{\circ}$ $\mathrm{C}$ were stored in desiccators for several months longer than those heat-treated at $1,900^{\circ} \mathrm{C}$. In view of the instability of these carbides with respect to air, it is reasonable to assume that the departure of these analyses from 100 percent may be attributed, in part, to oxidation of the specimens that occurred during storage periods of as long as 18 months. In all cases, the specimens were ground to pass a No. 200 U. S. Standard Sieve for X-ray analysis shortly after heat treatment and were stored in this condition. The expiration of the investigation prevented the determination of oxygen content.

The results of the chemical analyses of the alloys were not substituted for the nominal compositions for several reasons:

First, due to oxidation or hydration, the chemical composition of the samples is believed to have changed during the interval between X-ray and chemical analyses.

Second, some doubt exists concerning the cause of the failure of the analysis to total 100 percent. Even if the cause is definitely attributed to oxygen, there are no valid assumptions that can be made to permit the calculation of the composition that existed at the time of heat treatment.

Third, all of the heated alloys were not analyzed, and confusion would result from the attempt to correlate data in which part of the alloys were considered on the basis of nominal composition, and part on the basis of analyzed composition.



FIgure 3. Phases identified in the system $\mathrm{UC}-\mathrm{UC}_{2}-\mathrm{Be}_{2} \mathrm{C}$, in mole percent.

The alloys were heated for 2 hours at $1,700^{\circ} \mathrm{C}$, in argon and then oilquenched. Dots refer to preparations studied.

\section{Results and Discussion}

\subsection{Isothermal Section at $1,700^{\circ} \mathrm{C}$}

An isothermal section at $1,700^{\circ} \mathrm{C}$ was made of interactions within the system $\mathrm{UC}-\mathrm{UC}_{2}-\mathrm{Be}_{2} \mathrm{C}$ and in the binary boundary systems that are included. A constitutional diagram, prepared from the data, is shown in figure 3 . This figure represents the constitution of alloys after a $2-\mathrm{hr}$ heat treatment at $1,700^{\circ} \mathrm{C}$ and is not intended to represent an equilibrium phase diagram.

\section{a. The Binary System UC-Be ${ }_{2} \mathrm{C}$}

Data are presented in table 4 and figure 4 showing the relation between lattice parameters and composition in the system $\mathrm{UC}-\mathrm{Be}_{2} \mathrm{C}$ after quenching in oil from $1,700^{\circ} \mathrm{C}$. It can be seen that small additions of $\mathrm{Be}_{2} \mathrm{C}$ increase the unit-cell size of the UC phase. At the limit of solubility, 20 mole percent (or $2.9 \mathrm{wt}$ percent) of $\mathrm{Be}_{2} \mathrm{C}$, the volume of the $\mathrm{UC}$ unit-cell was increased by 1.6 percent. The broken line in figure 4 represents the type of results obtained early in the

TABLE 4. Composition and UC lattice parameters in the system $\mathrm{UC}-\mathrm{Be}_{2} \mathrm{C}$

Preparations were heated $2 \mathrm{hr}$ at $1,700^{\circ} \mathrm{C}$ in argon and then oil-quenched.

\begin{tabular}{|c|c|c|c|c|}
\hline \multirow[b]{2}{*}{ Alloy } & \multicolumn{2}{|c|}{ Nominal composition } & \multicolumn{2}{|c|}{$\mathrm{UC}_{\mathrm{ss}}$ parameters } \\
\hline & $\mathrm{Be}_{2} \mathrm{C}$ & $\mathrm{UC}$ & $\begin{array}{l}\text { Oil-quenched } \\
\text { (rapid cool- } \\
\text { ing) }\end{array}$ & $\begin{array}{l}\text { Quenched in } \\
\text { less rapid } \\
\text { cooling } \\
\text { media a }\end{array}$ \\
\hline $\begin{array}{l}44 \\
55 \\
56 \\
59\end{array}$ & $\begin{array}{c}\text { Mole } \% \\
0 \\
2 \\
4 \\
6 \\
8\end{array}$ & $\begin{array}{c}\text { Mole } \% \\
100 \\
98 \\
96 \\
94 \\
92\end{array}$ & $\begin{array}{ll} & A \\
& 4.962 \\
& 4.964 \\
\text { b } & 4.967 \\
\text { b } & 4.970 \\
& 4.972\end{array}$ & $\begin{array}{c}A \\
4.963 \\
4.965 \\
4.968 \\
4.972 \\
\end{array}$ \\
\hline $\begin{array}{l}43 \\
173 \\
174 \\
41\end{array}$ & $\begin{array}{l}10 \\
12 \\
14 \\
20 \\
30\end{array}$ & $\begin{array}{l}90 \\
88 \\
86 \\
80 \\
70\end{array}$ & $\begin{array}{l}\text { 4. } 974 \\
\text { 4. } 979 \\
\text { 4. } 981 \\
\text { 4. } 988 \\
\text { 4. } 985\end{array}$ & $\begin{array}{l}4.973 \\
4.972 \\
4.972\end{array}$ \\
\hline $\begin{array}{l}40 \\
39 \\
37\end{array}$ & $\begin{array}{l}40 \\
50 \\
70\end{array}$ & $\begin{array}{l}60 \\
50 \\
30\end{array}$ & $\begin{array}{l}\text { 4. } 989 \\
\text { 4. } 988 \\
\text { 4. } 992\end{array}$ & $\begin{array}{l}\text { 4. } 972 \\
\text { 4. } 973 \\
\text { 4. } 974\end{array}$ \\
\hline
\end{tabular}

a These data obtained on specimens that were cooled either in molten tin (mp $232^{\circ} \mathrm{C}$ ) or on tantalum wool.

b Pellets missed oil quench-cup. They were cooled less rapidly than those which were oil-quenched.

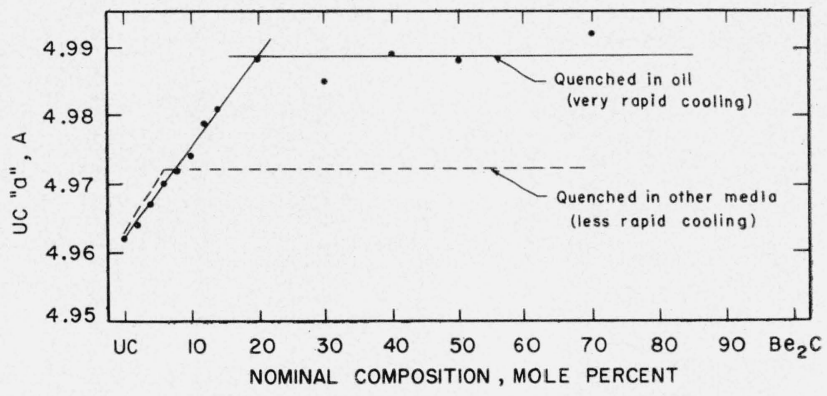

FIGURE 4. Lattice parameters of uranium carbide solid solutions in mixtures of $\mathrm{UC}$ and $\mathrm{Be}_{2} \mathrm{C}$.

The preparations were heated for 2 hours at $1,700^{\circ} \mathrm{C}$ in an argon atmosphere and then quenched in oil. 
investigation, when the specimens were dropped onto tantalum wool or into molten tin in a cooler part of the furnace rather than into quenching oil. The furnace quench, which resulted in a less rapid cooling, indicated a much lower solubility limit for $\mathrm{Be}_{2} \mathrm{C}$ in UC (6 mole percent) than was obtained with the oil quench (20 mole percent). Because precipitation or ex-solution occurs readily in these alloys, it seems likely that $\mathrm{X}$-ray examination with high-temperature equipment might show a still higher solubility for the same temperature.

\section{b. The Binary System UC-UC ${ }_{2}$}

The uranium-carbon system has been studied in other laboratories $[10,11]$. The conflicting nature of the proposed diagrams, the need for determining lattice parameter values, and the degree of interaction between phases made desirable a reinvestigation of that portion of the system between $\mathrm{UC}$ and $\mathrm{UC}_{2}$.

Uranium sesquicarbide, $\mathrm{U}_{2} \mathrm{C}_{3}$, was observed in the present investigation consistent with the conditions of stress and temperature described by Mallett, Gerds, and Vaughan [9]. The X-ray diffraction pattern described by Mallett was obtained with Fe $\mathrm{K}$ radiation and contained 23 lines with $a=8.088$ $\pm 0.001 \mathrm{~A}$. The pattern, obtained with $\mathrm{Cu} \mathrm{K \alpha}$ radiation, in this study, contained 14 additional high-angle reflections with $a=8.089 \pm 0.001 \mathrm{~A}$, based on the high-angle reflections. Because the pattern, obtained with $\mathrm{Cu} K \alpha$ radiation, has not been published, it is given in table 5. The pattern was obtained from a sample consisting of 50 mole percent of $\mathrm{UC}_{2}$ and 50 mole percent of $\mathrm{UC}$ heated at $1,600^{\circ}$ $\mathrm{C}$ in argon and cooled to room temperature in the furnace.

The results obtained in the present study are given in table 6 . The data indicate that $\mathrm{UC}$ enters into a solid-state reaction with as much as 27 mole percent of $\mathrm{U}_{2} \mathrm{C}_{3}$ (13.5 mole percent of $\mathrm{UC}_{2}$ ), to yield a single-phase region of UC solid solutions. These solid solutions show no significant lattice parameter change over this range of composition. It was found that alloy mixtures, such as 194 (table 6) with a carbon content sufficient to correspond to 24 mole percent of $\mathrm{U}_{2} \mathrm{C}_{3}$, showed only the pattern of $\mathrm{UC}$ solid solution after heat treatment. Experiments performed, using the X-ray methods previously described, showed that 5 mole percent of $\mathrm{U}_{2} \mathrm{C}_{3}$ could easily be detected in the presence of 95 percent of UC. For this reason, the first six alloys of table 6 were considered to be one-phase solid solutions, regardless of the fact that no parameter change was observed.

An independent estimate of the limit of solid solution was obtained from a comparison of the relative intensities of $\mathrm{U}_{2} \mathrm{C}_{3}$ and $\mathrm{UC}_{\mathrm{ss}}$ reflections of the X-ray patterns of two-phase alloys between 24 and 95.2 mole percent $\mathrm{U}_{2} \mathrm{C}_{3}$ (12 and 47.6 mole percent of $\mathrm{UC}_{2}$ ), with the relative intensities of known, unheated mixtures of $\mathrm{UC}$ and $\mathrm{U}_{2} \mathrm{C}_{3}$. The (220) reflection of UC at $2 \theta$ equals $52.1^{\circ}$ and the (510/439)
TABLE 5. X-ray diffraction data for the cubic compound $\mathrm{U}_{2} \mathrm{C}_{3}$ obtained with copper $\mathrm{K}_{\alpha_{1}}$ radiation

\begin{tabular}{|c|c|c|c|}
\hline$h k l$ & $\mathrm{Cu} \mathrm{K}_{\alpha_{1}}$ & $d$ & $a$ \\
\hline $\begin{array}{l}211 \\
220 \\
310 \\
321 \\
400 \\
332 \\
422 \\
510 / 431 \\
521 \\
440 \\
530 \\
611 / 532 \\
620 \\
541 \\
631 \\
444 \\
710 / 543 \\
721 / 633 / 552 \\
642 \\
730 \\
732 / 651 \\
800 \\
741 \\
653 \\
660 / 822 \\
750 / 831 / 743 \\
752 \\
840 \\
833 / 910 \\
761 / 921 / 655 \\
664 \\
754 / 930 / 851 \\
932 / 763 \\
844 \\
853 / 941 \\
772 / 10,1,1 \\
862 / 10,2,0\end{array}$ & $\begin{array}{c}29 \\
27.00 \\
31.26 \\
35.07 \\
41.76 \\
44.80 \\
53.07 \\
55.61 \\
58.10 \\
62.88 \\
64.98 \\
67.46 \\
71.89 \\
74.06 \\
76.21 \\
80.46 \\
82.55 \\
84.63 \\
88.81 \\
90.89 \\
92.97 \\
97.13 \\
99.25 \\
101.36 \\
105.63 \\
107.79 \\
109.98 \\
114.48 \\
116.76 \\
119.14 \\
124.03 \\
126.56 \\
129.20 \\
134.79 \\
137.82 \\
141.01 \\
148.21 \\
152.40\end{array}$ & $\begin{array}{l}\text { A } \\
\text { 3. } 300 \\
2.859 \\
2.556 \\
2.161 \\
2.021 \\
1.724 \\
1.651 \\
1.586 \\
1.477 \\
1.434 \\
1.387 \\
1.312 \\
1.279 \\
1.248 \\
1.193 \\
1.1676 \\
1.1442 \\
1.1008 \\
1.0809 \\
1.0621 \\
1.0274 \\
1.0111 \\
0.9956 \\
.9668 \\
.9534 \\
.9404 \\
.9159 \\
.9045 \\
.8933 \\
.8722 \\
.8623 \\
.8527 \\
.8343 \\
.8256 \\
.8171 \\
.8009 \\
.7931\end{array}$ & $\begin{array}{l}\text { A } \\
\end{array}$ \\
\hline \multicolumn{3}{|l|}{ Average. } & 8. 0890 \\
\hline
\end{tabular}

TABLE 6. Composition and lattice parameters in the system $\mathrm{UC}-\mathrm{UC}_{2}$

Preparations were heated $2 \mathrm{hr}$ at $1,700^{\circ} \mathrm{C}$ in argon and then oil-quenched.

\begin{tabular}{|c|c|c|c|c|c|}
\hline \multirow{2}{*}{ Alloy } & \multicolumn{2}{|c|}{ Nominal composition } & \multicolumn{3}{|c|}{ Lattice parameters of stable phases } \\
\hline & $\mathrm{UC}_{2}$ & $\mathrm{UC}$ & $\mathrm{UC}_{\mathrm{Bs}}$ & $\mathrm{U}_{2} \mathrm{C}_{3}$ & $\mathrm{UC}_{28 \mathrm{~s}}\left(a^{*}\right)^{\mathrm{a}}$ \\
\hline $\begin{array}{l}44 \ldots \ldots \\
88 \\
87 \\
86 \\
85\end{array}$ & $\begin{array}{c}\text { Mole \% } \\
0 \\
2 \\
4 \\
6 \\
8\end{array}$ & $\begin{array}{c}\text { Mole \% } \\
100 \\
98 \\
96 \\
94 \\
92\end{array}$ & $\begin{array}{l}\text { A } \\
\text { 4. } 962 \\
\text { 4. } 961 \\
\text { 4. } 964 \\
\text { 4. } 964 \\
\text { 4. } 964\end{array}$ & $\begin{array}{c}A \\
-1 \\
-\end{array}$ & $\begin{array}{c}A \\
-2 \\
-\end{array}$ \\
\hline $\begin{array}{l}194 \ldots \\
186 \\
187 \\
188 \\
84\end{array}$ & $\begin{array}{l}12 \\
15 \\
20 \\
25 \\
30\end{array}$ & $\begin{array}{l}88 \\
85 \\
80 \\
75 \\
70\end{array}$ & $\begin{array}{l}\text { 4. } 966 \\
\text { 4. } 964 \\
\text { 4. } 965 \\
\text { 4. } 964 \\
\text { 4. } 965\end{array}$ & $\begin{array}{l}8.09 \\
8.090 \\
8.090 \\
8.089\end{array}$ & 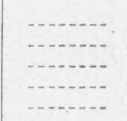 \\
\hline $\begin{array}{l}149 \ldots \\
192 \ldots \\
89 \\
146 \ldots \\
83 \ldots\end{array}$ & $\begin{array}{l}33.7 \\
40.5 \\
50 \\
60 \\
70\end{array}$ & $\begin{array}{l}66.3 \\
59.5 \\
50 \\
40 \\
30\end{array}$ & $\begin{array}{l}\text { 4. } 968 \\
\text { 4. } 967 \\
\text { 4. } 968 \\
-\end{array}$ & $\begin{array}{l}8.089 \\
8.090 \\
8.089 \\
8.089 \\
8.090\end{array}$ & $\begin{array}{l} \\
\text { (b) } \\
4.196\end{array}$ \\
\hline $\begin{array}{l}150 \ldots \\
101 \ldots \\
81 \ldots \\
80 \ldots \\
79 \ldots\end{array}$ & $\begin{array}{l}78.3 \\
90 \\
94 \\
96 \\
98\end{array}$ & $\begin{array}{c}21.7 \\
10 \\
6 \\
4 \\
2\end{array}$ & - & \begin{tabular}{c}
8.090 \\
\\
\hdashline
\end{tabular} & $\begin{array}{l}4.195 \\
4.194 \\
4.193 \\
4.194 \\
4.194\end{array}$ \\
\hline $67 \ldots$ & 100 & - & -..... & - & 4. 195 \\
\hline
\end{tabular}

$a a^{*}=\sqrt[3]{a^{2} c}$.

a $a^{*}=\sqrt[a]{a^{2} c}$.
b Phase identified, but in an amount too small to permit a determination of the lattice parameter. 


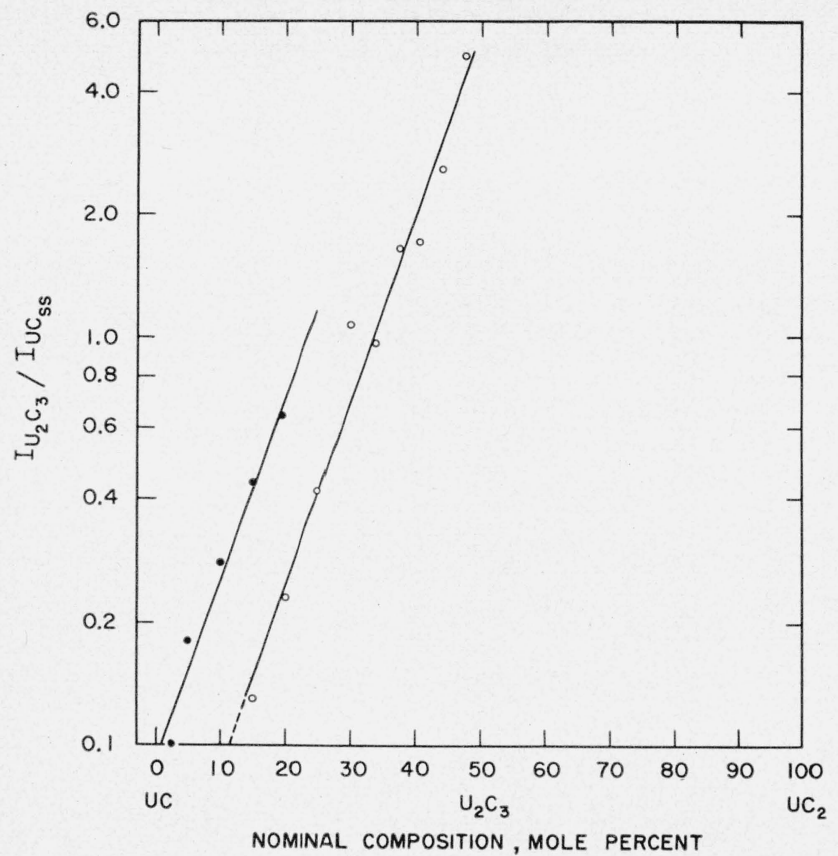

FIGURE 5. X-ray intensity ratio as a function of composition, for alloys between $\mathrm{UC}$ and $\mathrm{U}_{2} \mathrm{C}_{3}$.

Solid circles represent data obtained from unheated mixtures. Open circles represent data obtained from alloys heated for $2 \mathrm{hr}$ at $1,700^{\circ} \mathrm{C}$ in argon.

reflection of $\mathrm{U}_{2} \mathrm{C}_{3}$ at $2 \theta$ equals $58.1^{\circ}$ were selected for the intensity comparison of the heated and the unheated mixtures.

The ratios of $\mathrm{I}_{\mathrm{U}_{2} \mathrm{C}_{3}} / \mathrm{I}_{\mathrm{UC}}$, when plotted against composition on rectangular coordinate paper, appeared to follow a curved line. When the same data were plotted on semilogarithmic paper, a more nearly linear relationship was obtained. For this reason, the data were fitted by curves of the form $y=a b^{x}$, using the method of least squares. These are the straight lines through the data points in figure 5 .

From the curves, the intensity ratios associated with a given $\mathrm{U}_{2} \mathrm{C}_{3}$ content may be found for both the heated alloys and the known mixtures. The much smaller intensity ratio of a heated alloy, as compared with that of a known mixture of the same composition, indicate that the amount of "free" $\mathrm{U}_{2} \mathrm{C}_{3}$ has decreased as a result of the heat treatment. The distance between the curves, measured parallel to the $x$-axis, represents the amount of decrease in "free" $\mathrm{U}_{2} \mathrm{C}_{3}$. The value obtained from the curves in this way, about 20 mole percent of $\mathrm{U}_{2} \mathrm{C}_{3}(10$ mole percent of $\mathrm{UC}_{2}$ ), may be used as an estimate of the solubility limit of $\mathrm{U}_{2} \mathrm{C}_{3}$ in $\mathrm{UC}$, and confirms the presence of solid solubility without parameter change.

The single-phase region of $\mathrm{UC}_{2}$ solid solutions extends to about 32 mole percent of $\mathrm{U}_{2} \mathrm{C}_{3}$ (16 mole percent of UC), without appreciable parameter change. An insufficient number of alloys was examined in the field $\mathrm{UC}_{2 \mathrm{ss}}+\mathrm{U}_{2} \mathrm{C}_{3}$ to allow an estimate of the solubility limit based on intensity measurements. No evidence has been found for a singlephase field for $\mathrm{U}_{2} \mathrm{C}_{3}$ at $1,700^{\circ} \mathrm{C}$.
TABLE 7. Composition and lattice parameters in the system $\mathrm{UC}_{2}-\mathrm{Be}_{2} \mathrm{C}$

Preparations were heated $2 \mathrm{hr}$ at $1,700^{\circ} \mathrm{C}$. in argon and then oil-quenched.

\begin{tabular}{|c|c|c|c|}
\hline \multirow{2}{*}{ Alloy } & \multicolumn{2}{|c|}{$\begin{array}{l}\text { Nominal compo- } \\
\text { sition }\end{array}$} & \multirow{2}{*}{$\begin{array}{l}\text { Lattice } \\
\text { parameters } \\
\mathrm{UC}_{2}\left(a^{*}\right)^{\mathrm{a}}\end{array}$} \\
\hline & $\mathrm{UC}_{2}$ & $\mathrm{Be}_{2} \mathrm{C}$ & \\
\hline $\begin{array}{c}67 \\
74 \\
75 \\
76 \\
76 \\
76\end{array}$ & $\begin{array}{c}\text { Mole \% } \\
100 \\
98 \\
96 \\
94 \\
92\end{array}$ & $\begin{array}{c}\text { Mole \% } \\
2 \\
4 \\
6 \\
8\end{array}$ & $\begin{array}{l}\text { A } \\
\text { 4. } 195 \\
\text { 4. } 196 \\
\text { 4. } 196 \\
\text { 4. } 193 \\
\text { 4. } 194\end{array}$ \\
\hline $\begin{array}{l}66 \\
195 \\
196 \\
78\end{array}$ & $\begin{array}{l}90 \\
88 \\
86 \\
85 \\
84\end{array}$ & $\begin{array}{l}10 \\
12 \\
14 \\
15 \\
16\end{array}$ & $\begin{array}{l}4.195 \\
4.194 \\
4.195 \\
\text { 4. } 194 \\
4.194\end{array}$ \\
\hline $\begin{array}{l}198 \\
199 \\
62\end{array}$ & $\begin{array}{l}82 \\
78 \\
30\end{array}$ & $\begin{array}{l}18 \\
22 \\
70\end{array}$ & $\begin{array}{l}\text { 4. } 196 \\
\text { 4. } 195 \\
\text { 4. } 195\end{array}$ \\
\hline
\end{tabular}

a $a^{*}=\sqrt[3]{a^{2} c}$.

\section{c. The Binary System $\mathrm{UC}_{2}-\mathrm{Be}_{2} \mathrm{C}$}

Data are presented in table 7 for alloy preparations in the $\mathrm{UC}_{2}$-rich end of the system. It can be seen that $\mathrm{Be}_{2} \mathrm{C}$ has no effect on the $\mathrm{UC}_{2}$ unit-cell size in the quenched alloys obtained after heating $2 \mathrm{hr}$ at $1,700^{\circ} \mathrm{C}$. in argon. In this particular binary system, involving the carbides of a very heavy metal and a very light metal, the X-ray method for the identification of phases is especially inadequate because of the wide difference in $\bar{X}$-ray absorption characteristics. On the basis of $\mathrm{X}$-ray evidence alone, there is no indication of solubility of $\mathrm{Be}_{2} \mathrm{C}$ in $\mathrm{UC}_{2}$.

\section{d. Ternary Alloys Within the System UC-UC $\mathrm{UC}_{2}-\mathrm{Be}_{2} \mathrm{C}$}

The data obtained on ternary alloys along several sections within the system $\mathrm{UC}-\mathrm{UC}_{2}-\mathrm{Be}_{2} \mathrm{C}$ are given in tables 8 and 9 . Although the alloys are not identified by number in figure 3 , the compositions given in the tables should identify the individual alloys along the respective section lines.

The alloys described in table 9 are, with few exceptions, within the UC single-phase field. The data give a satisfactory representation of the parametric surface within this region. It can be seen that the parameter increase along the sections, in the direction away from $\mathrm{UC}$, is greatest along the $1: 1$ section. Vertical sections through the parametric surface, perpendicular to the $1: 1$ section, would show parameter maxima near the $1: 1$ section.

Five sections were studied (table 8), which extend into or cross the three-phase field in figure 3. For alloys along the sections, the $\mathrm{UC}_{\mathrm{ss}}$ parameters increased to a value of $a=5.002 \pm 0.005 \mathrm{~A}$ and then remained essentially constant. Those alloys that had $\mathrm{UC}_{\mathrm{ss}}$ parameters within these limits were considered to be within the three-phase area and were used in locating the three-phase boundary. Along those sec- 
TABLE 8. Composition and lattice parameters along several sections within the system $\mathrm{UC}-\mathrm{UC}_{2}-\mathrm{Be}_{2} \mathrm{C}$

Preparations were heated for $2 \mathrm{hr}$ at $1,700^{\circ} \mathrm{C}$ in argon and then oil-quenched.

\begin{tabular}{|c|c|c|c|c|c|c|c|}
\hline \multirow{2}{*}{ Alloy } & \multicolumn{3}{|c|}{ Nominal composition } & \multicolumn{4}{|c|}{ Lattice parameters } \\
\hline & UC & $\mathrm{UC}_{2}$ & $\mathrm{Be}_{2} \mathrm{C}$ & $\mathrm{UC}_{88}$ & $\begin{array}{c}\mathrm{UC}_{2 \mathrm{sg}} \\
\left(a^{*}\right)^{\mathrm{a}}\end{array}$ & $\mathrm{U}_{2} \mathrm{C}_{3}$ & $\mathrm{Be}_{2} \mathrm{C}$ \\
\hline $\begin{array}{c}40 \\
90 \ldots \\
91 \\
92 \\
93 \\
94 \\
95 \\
95 \\
96 \\
97 \\
98 \\
99 \\
100\end{array}$ & $\begin{array}{c}\text { Mole } \% \\
60 \\
55 \\
50 \\
45 \\
40 \\
35 \\
30 \\
25 \\
20 \\
15 \\
10 \\
5\end{array}$ & $\begin{array}{c}\text { Mole \% } \\
5 \\
10 \\
15 \\
20 \\
25 \\
30 \\
35 \\
40 \\
45 \\
50 \\
55\end{array}$ & $\begin{array}{c}\text { Mole } \% \\
40 \\
40 \\
40 \\
40 \\
40 \\
40 \\
40 \\
40 \\
40 \\
40 \\
40 \\
40\end{array}$ & $\begin{array}{l}\text { A } \\
\text { 4. } 989 \\
\text { 4. } 987 \\
\text { 4. } 998 \\
\text { 5. } 000 \\
\text { 5. } 002 \\
\text { 5. } 005 \\
\text { 5. } 007 \\
\text { 5. } 005 \\
\text { 5. } 001 \\
\\
\\
\end{array}$ & $\begin{array}{l}\text { A } \\
\text { (b) } \\
\text { (b) } \\
\text { (b) } \\
\text { (b) } \\
4.198 \\
4.197 \\
4.196 \\
4.194 \\
4.195 \\
4.191 \\
4.192 \\
4.192\end{array}$ & $\begin{array}{c}A \\
\cdots \\
\cdots \\
\cdots \\
\cdots \\
\cdots \\
\cdots \\
\cdots \\
\cdots \\
\cdots \\
\cdots\end{array}$ & $\begin{array}{c}A \\
\text { (b) } \\
\text { (b) } \\
\text { (b) } \\
\text { (b) } \\
\text { (b) }\end{array}$ \\
\hline $\begin{array}{r}37 \ldots \\
108 \\
109 \ldots \\
110 \ldots \\
111 \ldots \\
112 \ldots \\
62 \ldots\end{array}$ & $\begin{array}{r}30 \\
25 \\
20 \\
15 \\
10 \\
5 \\
-\end{array}$ & $\begin{array}{r}5 \\
10 \\
15 \\
20 \\
25 \\
30\end{array}$ & $\begin{array}{l}70 \\
70 \\
70 \\
70 \\
70 \\
70 \\
70\end{array}$ & $\begin{array}{l}4.992 \\
5.000 \\
5.000 \\
5.001 \\
\ldots \\
\ldots\end{array}$ & $\begin{array}{l}\text { (b) } \\
\text { (b) } \\
\text { (b) } \\
4.198 \\
4.195 \\
4.197 \\
4.195\end{array}$ & $\begin{array}{l} \\
\ldots \ldots \\
\ldots \ldots \\
\ldots \ldots \\
\ldots \ldots \\
\ldots \ldots\end{array}$ & $\begin{array}{l}\text { 4. } 342 \\
\text { 4. } 342 \\
\text { 4. } 342 \\
\text { 4. } 342 \\
\text { 4. } 342 \\
\text { 4. } 341 \\
\text { 4. } 342\end{array}$ \\
\hline $\begin{array}{l}177 \\
178 \\
179 \\
180 \\
181 \\
182 \\
183\end{array}$ & $\begin{array}{l}35 \\
35 \\
35 \\
35 \\
35 \\
35 \\
35\end{array}$ & $\begin{array}{l}65 \\
62.5 \\
60 \\
57.5 \\
55 \\
52.5 \\
50\end{array}$ & $\begin{array}{l}2.5 \\
5 \\
7.5 \\
10 \\
12.5 \\
15\end{array}$ & \begin{tabular}{l} 
(b) \\
\hdashline$(\mathrm{b})$ \\
5.004 \\
5.002 \\
5.003
\end{tabular} & $\begin{array}{l}\text { 4. } 196 \\
\text { 4. } 196 \\
4.198 \\
4.197 \\
4.196 \\
4.198 \\
4.197\end{array}$ & $\begin{array}{l}8.090 \\
8.089 \\
8.090 \\
8.089 \\
8.091 \\
\end{array}$ & 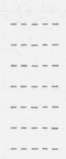 \\
\hline $\begin{array}{l}188 \\
189 \\
117 \\
118 \\
190 \\
119 \\
120 \\
121\end{array}$ & $\begin{array}{l}75 \\
72.5 \\
70 \\
65 \\
62.5 \\
60 \\
55 \\
50\end{array}$ & $\begin{array}{l}25 \\
25 \\
25 \\
25 \\
25 \\
25 \\
25 \\
25\end{array}$ & $\begin{array}{l}2.5 \\
5 \\
10 \\
12.5 \\
15 \\
20 \\
25\end{array}$ & $\begin{array}{l}\text { 4. } 964 \\
\text { 4. } 970 \\
\text { 4. } 976 \\
\text { 4. } 991 \\
\text { 5. } 002 \\
\text { 5. } 003 \\
\text { 5. } 004 \\
\text { 5. } 002\end{array}$ & $\begin{array}{l}\text { (b) } \\
\text { (b) } \\
\text { (b) } \\
\text { (b) } \\
\text { (b) } \\
\text { (b) } \\
\text { (b) } \\
\text { (b) }\end{array}$ & $\begin{array}{l}8.090 \\
8.089 \\
8.088 \\
8.089 \\
8.090 \\
-\ldots . \\
\\
\end{array}$ & 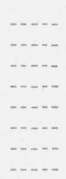 \\
\hline $\begin{array}{l}68 \\
69 \\
70 \\
71 \\
72 \\
\end{array}$ & $\begin{array}{l}48.1 \\
46.2 \\
44.9 \\
42.9 \\
40.2\end{array}$ & $\begin{array}{l}48.1 \\
46.2 \\
43.6 \\
41.6 \\
40.3\end{array}$ & $\begin{array}{r}3.8 \\
7.6 \\
11.5 \\
15.4 \\
19.5\end{array}$ & $\begin{array}{l}4.976 \\
4.995 \\
5.007 \\
5.005 \\
5.005\end{array}$ & $\begin{array}{l}\text { 4. } 197 \\
4.200 \\
4.195 \\
4.201 \\
4.198\end{array}$ & \begin{tabular}{c}
8.090 \\
\hdashline \\
\end{tabular} & ב. \\
\hline
\end{tabular}

a $a^{*}=\sqrt[3]{a^{2} c}$.

bhase identified but in an amount too small to permit a determination of the lattice parameter.

tions where $\mathrm{U}_{2} \mathrm{C}_{3}$ and $\mathrm{UC}_{\mathrm{ss}}$ were identified, the disappearance of $\mathrm{U}_{2} \mathrm{C}_{3}$ indicated that the boundary of the three-phase area had been crossed and was used in locating the boundary.

The stability relations of uranium sesquicarbide are not clearly understood. The conditions of stress and temperature necessary to form or stabilize $\mathrm{U}_{2} \mathrm{C}_{3}$, as described by Mallett et al. [9], were verified in the present work with the same alloys. As these alloys "aged," the sesquicarbide failed to appear, either in binary or ternary mixtures. Mixtures made from the freshly prepared alloys, 361 and 369, however, gave results compatible with those reported by Mallett.

$\mathrm{U}_{2} \mathrm{C}_{3}$ was found in the present experiments as a constituent phase in only a limited portion of the ternary diagram. It was not found in any preparation that contained more than 12.5 mole percent of $\mathrm{Be}_{2} \mathrm{C}$.

Three possible forms of an equilibrium phase diagram might be postulated. In the first such form, figure 6 , a join would connect $\mathrm{U}_{2} \mathrm{C}_{3}$ and $\mathrm{Be}_{2} \mathrm{C}$. In this form of diagram the absence of $\mathrm{U}_{2} \mathrm{C}_{3}$ within the central portion of the system, under the conditions
TABLE 9. Composition and lattice parameters of UC solidsolution alloys within the system $\mathrm{UC}-\mathrm{UC}_{2}-\mathrm{Be}_{2} \mathrm{C}$

Preparations were heated $2 \mathrm{hr}$ at $1,700^{\circ} \mathrm{C}$ in argon and then oil-quenched.

\begin{tabular}{|c|c|c|c|c|}
\hline \multirow{2}{*}{ Alloy } & \multicolumn{2}{|c|}{ Nominal composition } & \multicolumn{2}{|c|}{ Lattice parameters } \\
\hline & $\mathrm{UC}$ & $\mathrm{UC}_{2}: \mathrm{Be}_{2} \mathrm{C}$ & $\mathrm{UC}$ & $\mathrm{U}_{2} \mathrm{C}_{3}$ \\
\hline $\begin{array}{l}151 \\
152 \\
153 \\
154 \\
155 \\
156 \\
157\end{array}$ & $\begin{array}{c}\text { Mole \% } \\
95 \\
92.5 \\
90 \\
87.5 \\
85 \\
82.5 \\
80\end{array}$ & $\begin{array}{c}\text { Mole } \% \\
3: 1 \\
3: 1 \\
3: 1 \\
3: 1 \\
3: 1 \\
3: 1 \\
3: 1\end{array}$ & $\begin{array}{c}\text { A } \\
4.966 \\
4.968 \\
4.967 \\
4.969 \\
4.971 \\
4.974 \\
4.972\end{array}$ & $\begin{array}{c}A \\
\text { (a) } \\
8.090\end{array}$ \\
\hline $\begin{array}{l}158 \\
159 \\
160 \\
161 \\
163 \\
164 \\
165 \\
204 \\
205 \\
206\end{array}$ & $\begin{array}{l}97.5 \\
95 \\
92.5 \\
90 \\
87.5 \\
85 \\
82.5 \\
80 \\
77.5 \\
75 \\
72.5 \\
70\end{array}$ & $\begin{array}{l}1: 1 \\
1: 1 \\
1: 1 \\
1: 1 \\
1: 1 \\
1: 1 \\
1: 1 \\
1: 1 \\
1: 1 \\
1: 1 \\
1: 1 \\
1: 1\end{array}$ & $\begin{array}{l}\text { 4. } 963 \\
\text { 4. } 966 \\
\text { 4. } 969 \\
\text { 4. } 969 \\
\text { 4. } 976 \\
\text { 4. } 977 \\
\text { 4. } 984 \\
\text { 4. } 989 \\
\text { 4. } 992 \\
\text { 4. } 993 \\
\text { 4. } 997 \\
\text { 4. } 998\end{array}$ & (a) \\
\hline $\begin{array}{l}166 \\
167 \\
168 \\
169 \\
170 \\
171 \\
172\end{array}$ & $\begin{array}{l}95 \\
92.5 \\
90 \\
87.5 \\
85 \\
82.5 \\
80 \\
77.5 \\
75 \\
72.5\end{array}$ & $\begin{array}{l}1: 3 \\
1: 3 \\
1: 3 \\
1: 3 \\
1: 3 \\
1: 3 \\
1: 3 \\
1: 3 \\
1: 3 \\
1: 3\end{array}$ & $\begin{array}{l}\text { 4. } 969 \\
\text { 4. } 972 \\
\text { 4. } 976 \\
\text { 4. } 981 \\
\text { 4. } 981 \\
\text { 4. } 987 \\
\text { 4. } 982 \\
\text { 4. } 986 \\
\text { 4. } 988 \\
\text { 4. } 989\end{array}$ & (n. \\
\hline $\begin{array}{l}200 \ldots 1 \\
201 \\
202 \\
207\end{array}$ & $\begin{array}{l}77.5 \\
75 \\
72.5 \\
75\end{array}$ & $\begin{array}{l}2: 1 \\
\text { 1. } 5: 1 \\
1.2: 1 \\
1: 1.5\end{array}$ & $\begin{array}{l}\text { 4. } 980 \\
\text { 4. } 992 \\
\text { 4. } 997 \\
\text { 4. } 992\end{array}$ & 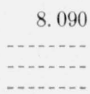 \\
\hline
\end{tabular}

a Phase identified, but in an amount too small to permit a determination of the lattice parameter.

of the present experiments, would result from the nonattainment of equilibrium, and $\mathrm{U}_{2} \mathrm{C}_{3}$ would increase at the expense of $\mathrm{UC}_{2}$ or $\mathrm{UC}$ as equilibrium was approached. In the second form of an equilibrium diagram, $\mathrm{U}_{2} \mathrm{C}_{3}$ would not appear. The presence of the $\mathrm{U}_{2} \mathrm{C}_{3}$ phase in the alloys would be a nonequilibrium condition, and the amount of $\mathrm{U}_{2} \mathrm{C}_{3}$ would decrease as equilibrium was approached. Another possible explanation of the occurrence of $\mathrm{U}_{2} \mathrm{C}_{3}$, within the ternary system, is one requiring the postulation of a compound in the $\mathrm{UC}-\mathrm{Be}_{2} \mathrm{C}$ system at about 25 to 35 percent of $\mathrm{Be}_{2} \mathrm{C}$. X-ray patterns within this region indicate a cubic, single-phase material with parameters slightly larger than UC, and have been interpreted merely as a solid solution of $\mathrm{Be}_{2} \mathrm{C}$ in $\mathrm{UC}$, with beryllium substituting for carbon in the interstitial uranium-carbon compound. It is possible, however, that a compound $3 \mathrm{UC} \cdot \mathrm{Be}_{2} \mathrm{C}$ or $2 \mathrm{UC} \cdot \mathrm{Be}_{2} \mathrm{C}$ may exist and form a complete series of solid solutions with pure UC. Binary joins would exist between both $\mathrm{U}_{2} \mathrm{C}_{3}$ and $\mathrm{UC}_{2}$ and the postulated compound. This explanation would satisfactorily explain the observed occurrence of $\mathrm{U}_{2} \mathrm{C}_{3}$, without postulating varying amounts of stress on a material that does not seem to have a varying composition. The possible occurrence of a hypothetical compound is suggested as a convenient method for making the results compatible with the phase rule, but no defi- 


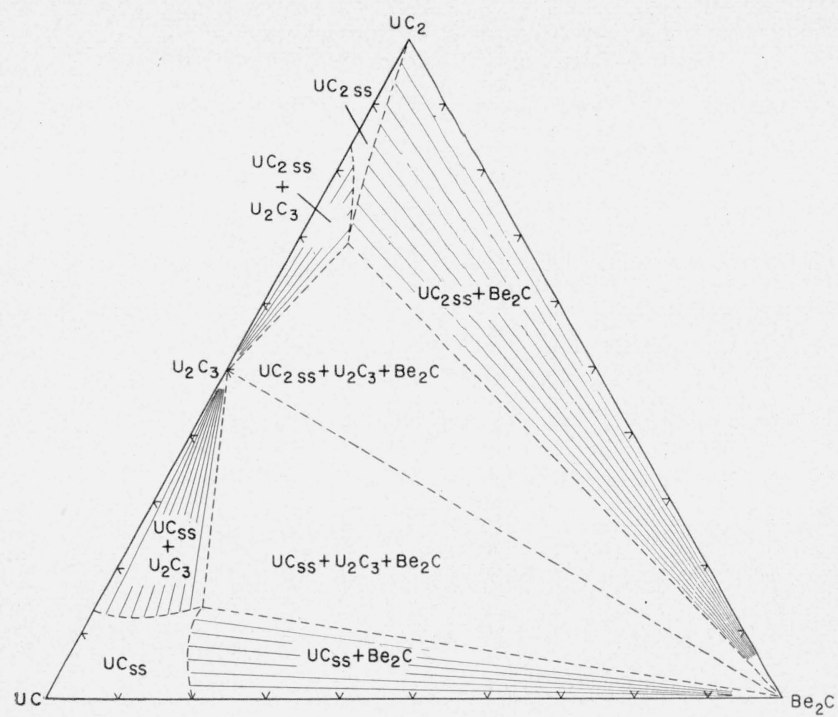

FIGURE 6. Most probable equilibrium diagram for the system $\mathrm{UC}-\mathrm{UC}_{2}-\mathrm{Be}_{2} \mathrm{C}$ at $1,700^{\circ} \mathrm{C}$, in mole percent.

nite evidence of its occurrence was found. Of these three possible forms of an equilibrium diagram for the system, it is believed that the first, figure 6 , is the most probable.

The boundary between the fields of $\mathrm{UC}_{\mathrm{ss}}$ and $\mathrm{UC}_{\mathrm{ss}}+\mathrm{U}_{2} \mathrm{C}_{3}$ is clearly established because 1- and 2phase alloys in these regions can be readily differentiated by X-ray methods. The boundary between the fields of $\mathrm{UC}_{\mathrm{ss}}$ and $\mathrm{UC}_{\mathrm{ss}}+\mathrm{Be}_{2} \mathrm{C}$, on the other hand, can only be approximated, because the $\mathrm{X}$-ray method fails to distinguish between 1- and 2phase ternary alloys involving $\mathrm{UC}_{\mathrm{ss}}$ and $\mathrm{Be}_{2} \mathrm{C}$.

The data and discussion of alloys in table 6 indicate the extent of the $\mathrm{UC}_{2}$ single-phase alloys in the binary system $\mathrm{UC}^{-\mathrm{UC}_{2}}$. Evidence has not been obtained to prove or to disprove the existence of single-phase $\mathrm{UC}_{2}$ alloys in the binary system $\mathrm{UC}_{2}-$ $\mathrm{Be}_{2} \mathrm{C}$. The assignment of a field to single-phase $\mathrm{UC}_{2}$ alloys is in recognition of its existence rather than an approximation of the extent of the field.

\subsection{Isothermal Study at $1,900^{\circ} \mathrm{C}$}

\section{a. The Binary System UC-UC U $_{2}$}

The composition and lattice parameters of constituent phases of the alloys heated at $1,900^{\circ} \mathrm{C}$ are given in table 10 . All preparations intermediate between the carbide end members are shown to consist of the two phases $\mathrm{UC}$ and $\mathrm{UC}_{2}$. There is no apparent relation between composition and unit-cell size.

\section{b. The Binary System UC-Be ${ }_{2} \mathrm{C}$}

The composition and X-ray data for alloys between $\mathrm{UC}$ and $\mathrm{Be}_{2} \mathrm{C}$ are given in table 11. Alloys 35, 36, and 37 are not on the join between $\mathrm{UC}$ and $\mathrm{Be}_{2} \mathrm{C}$ because of an excess of carbon. With the starting materials then available, additions of either beryllium
TABLE 10. Composition and lattice parameters in the system $\mathrm{UC}-\mathrm{UC}_{2}$

Preparations were heated $2 \mathrm{hr}$ at $1,900^{\circ} \mathrm{C}$ in argon and then oil-quenched.

\begin{tabular}{|c|c|c|c|c|}
\hline \multirow{2}{*}{ Alloy } & \multicolumn{2}{|c|}{ Nominal composition } & \multicolumn{2}{|c|}{ Lattice parameters } \\
\hline & $\mathrm{UC}$ & $\mathrm{UC}_{2}$ & $\mathrm{UC}$ & $\mathrm{UC}_{2}\left(a^{*}\right)^{\mathrm{a}}$ \\
\hline $\begin{array}{r}44 \\
85 \\
187 \\
84 \\
192 \\
89 \\
146 \\
83 \\
150 \\
101 \\
67\end{array}$ & $\begin{array}{c}\text { Mole } \% \\
100 \\
92 \\
80 \\
70 \\
59.5 \\
50 \\
40 \\
30 \\
21.7 \\
10\end{array}$ & $\begin{array}{c}\text { Mole } \% \\
8 \\
20 \\
30 \\
40.5 \\
50 \\
60 \\
70 \\
78.3 \\
90 \\
100\end{array}$ & $\begin{array}{l}\text { A. } \\
4.963 \\
4.965 \\
4.967 \\
4.968 \\
4.963 \\
4.966 \\
4.964 \\
4.963 \\
4.965 \\
\text { (b) } \\
\text { (b) }\end{array}$ & $\begin{array}{l}\text { A } \\
\text { (b) } \\
\text { (b) } \\
\text { 4. } 207 \\
\text { 4. } 199 \\
\text { 4. } 201 \\
\text { 4. } 200 \\
\text { 4. } 197 \\
\text { 4. } 199 \\
4.197 \\
4.202\end{array}$ \\
\hline
\end{tabular}

a $a^{*}=\sqrt[3]{a^{2} c}$.

b Phase identified but in an amount too small to permit a determination of the lattice parameter.

TABLE 11. Composition and lattice parameters in the system $\mathrm{UC}-\mathrm{Be}_{2} \mathrm{C}$

Preparations were heated for $2 \mathrm{hr}$ at $1,900^{\circ} \mathrm{C}$ in argon and then oil-quenched.

\begin{tabular}{|c|c|c|c|c|c|c|}
\hline \multirow{2}{*}{ Alloy } & \multicolumn{3}{|c|}{ Nominal composition } & \multicolumn{3}{|c|}{ Lattice parameters } \\
\hline & $\mathrm{UC}$ & $\mathrm{UC}_{2}$ & $\mathrm{Be}_{2} \mathrm{C}$ & $\mathrm{UC}_{8 \mathrm{~B}}$ & $\mathrm{UC}_{2}$ & $\mathrm{Be}_{2} \mathrm{C}$ \\
\hline $\begin{array}{l}44 \\
43 \\
42 \\
41 \\
40 \\
39 \\
39 \\
37 \\
36 \\
35 \\
26\end{array}$ & $\begin{array}{c}\text { Mole \% } \\
100 \\
90 \\
80 \\
70 \\
60 \\
50 \\
40 \\
29.6 \\
19.3 \\
9.1 \\
\end{array}$ & $\begin{array}{r}\text { Mole \% } \\
\\
0.4 \\
9 \\
9\end{array}$ & $\begin{array}{r}\text { Mole \% } \\
10 \\
20 \\
30 \\
40 \\
50 \\
60 \\
70 \\
80 \\
90 \\
100\end{array}$ & $\begin{array}{l}A \\
4.963 \\
4.970 \\
4.978 \\
4.982 \\
4.990 \\
4.987 \\
4.993 \\
4.995 \\
4.996 \\
5.002 \\
(\mathrm{a})\end{array}$ & $\begin{array}{c}A \\
\\
(a) \\
\text { (a) } \\
\text { (a) } \\
\text { (a) } \\
\text { (a) }\end{array}$ & $\begin{array}{c}\text { A } \\
\text { (a) } \\
\text { (a) } \\
\text { (a) } \\
4.342 \\
4.343\end{array}$ \\
\hline
\end{tabular}

a Phase identified, but in an amount too small to permit a determination of the lattice parameter.

or uranium metal would have been required to yield compositions on the join. Both the volatilization of beryllium and the gain in carbon from the specimen holder, during heating, could have resulted in further departures from the binary join. The occurrence of $\mathrm{UC}_{2}$ in the alloys at the $\mathrm{Be}_{2} \mathrm{C}$ end of the system may have resulted from these types of compositional changes. The tabulated data show UC solid solutions with increasing lattice parameters between 0 and 40 mole percent (7.4 wt percent) $\mathrm{Be}_{2} \mathrm{C}$. The marked change in slope of the parameter-composition curve at 40 mole percent of $\mathrm{Be}_{2} \mathrm{C}$ indicates the limit of solubility of $\mathrm{Be}_{2} \mathrm{C}$ in UC. Thus, it can be seen that the solubility of $\mathrm{Be}_{2} \mathrm{C}$ in $\mathrm{UC}$ is twice as large at $1,900^{\circ} \mathrm{C}$ as it was found to be at $1,700^{\circ} \mathrm{C}$. An explanation for the smaller slope within the twophase region is given in section 5.3.

\section{c, The Binary System $\mathrm{UC}_{2}-\mathrm{Be}_{2} \mathrm{C}$}

The data obtained for the alloys within this system, reacted at $1,900^{\circ} \mathrm{C}$, are given in table 12 . The lattice parameters of the $\mathrm{UC}_{2}$ phase showed no systematic variation with composition. $\mathrm{Be}_{2} \mathrm{C}$ could be positively identified only in those mixtures made up to contain 40-mole percent ( $7 \mathrm{wt}$ percent) or more 
TABLE 12. Composition and lattice parameters in the system $\mathrm{UC}_{2}-\mathrm{Be}_{2} \mathrm{C}$

Preparations were heated for $2 \mathrm{hr}$ at $1,900^{\circ} \mathrm{C}$ in argon and then oil-quenched.

\begin{tabular}{|c|c|c|c|c|c|}
\hline \multirow{2}{*}{ Alloy } & \multicolumn{2}{|c|}{$\begin{array}{l}\text { Nominal com - } \\
\text { position }\end{array}$} & \multicolumn{3}{|c|}{ Lattice parameters } \\
\hline & $\mathrm{UC}_{2}$ & $\mathrm{Be}_{2} \mathrm{C}$ & $\begin{array}{l}\mathrm{UC}_{2} \\
\left(a^{*}\right)^{\mathrm{a}}\end{array}$ & $\mathrm{UC}$ & $\mathrm{Be}_{2} \mathrm{C}$ \\
\hline $\begin{array}{l}67 \\
66 \\
65 \\
73 \\
64 \\
63 \\
47 \\
62 \\
61 \\
60 \\
26 \\
\ldots\end{array}$ & $\begin{array}{c}\text { Mole } \% \\
100 \\
90 \\
80 \\
70 \\
60 \\
50 \\
40 \\
30 \\
20 \\
10\end{array}$ & $\begin{array}{c}\text { Mole } \% \\
10 \\
20 \\
30 \\
40 \\
50 \\
60 \\
70 \\
80 \\
90 \\
100\end{array}$ & $\begin{array}{l}\text { A } \\
\text { 4. } 202 \\
\text { 4. } 196 \\
4.200 \\
\text { 4. } 197 \\
\text { 4. } 198 \\
\text { 4. } 196 \\
\text { 4. } 200 \\
\text { 4. } 199 \\
\text { 4. } 199 \\
\text { 4. } 202 \\
\text { (b) }\end{array}$ & $\begin{array}{l}A \\
\text { (b) } \\
\text { (b) } \\
\text { (b) } \\
\text { (b) } \\
\text { (b) } \\
\text { (b) } \\
\text { (b) } \\
\text { (b) } \\
\text { (b) } \\
\text { (b) } \\
\text { (b) }\end{array}$ & $\begin{array}{c}A \\
\text { (b) } \\
(\mathrm{c}) \\
(\mathrm{c}) \\
(\mathrm{b}) \\
\text { (b) } \\
\text { (b) } \\
\text { (b) } \\
4.343 \\
4.343 \\
4.343\end{array}$ \\
\hline
\end{tabular}

a $a^{*}=\sqrt[3]{a^{2} c}$

Phase identified, but in an amount too small to permit a determination of the lattice parameter.

Identification of the phase questionable.

TABLE 13. Composition and lattice parameters along several sections within the system $\mathrm{UC}-\mathrm{UC}_{2}-\mathrm{Be}_{2} \mathrm{C}$

Preparations were heated for $2 \mathrm{hr}$ at $1,900^{\circ} \mathrm{C}$ in argon and then oil-quenched.

\begin{tabular}{|c|c|c|c|c|c|c|}
\hline \multirow{2}{*}{ Alloy } & \multicolumn{3}{|c|}{ Nominal composition } & \multicolumn{3}{|c|}{ Lattice parameters } \\
\hline & $\mathrm{UC}$ & $\mathrm{UC}_{2}$ & $\mathrm{Be}_{2} \mathrm{C}$ & $\mathrm{UC}$ & $\begin{array}{l}\mathrm{UC}_{2} \\
\left(a^{*}\right)^{\mathrm{a}}\end{array}$ & $\mathrm{Be}_{2} \mathrm{C}$ \\
\hline $\begin{array}{l}40 \\
90 \\
91 \\
92 \\
93 \\
94 \\
95\end{array}$ & $\begin{array}{c}\text { Mole \% } \\
60 \\
55 \\
50 \\
45 \\
40 \\
35 \\
30\end{array}$ & $\begin{array}{c}\text { Mole } \% \\
5 \\
10 \\
15 \\
20 \\
25 \\
30\end{array}$ & $\begin{array}{c}\text { Mole \% } \\
40 \\
40 \\
40 \\
40 \\
40 \\
40 \\
40\end{array}$ & $\begin{array}{c}\text { A } \\
\text { 4. } 990 \\
4.995 \\
4.989 \\
4.998 \\
\text { 4. } 999 \\
5.002 \\
5.004\end{array}$ & $\begin{array}{l}A \\
\text { (b) } \\
\text { (b) } \\
\text { (b) } \\
\text { (b) } \\
\text { (b) } \\
\text { (b) }\end{array}$ & $\begin{array}{c}A \\
\text { (b) }\end{array}$ \\
\hline $\begin{array}{l}96 \\
97 \\
98 \\
99 \\
100 \\
64\end{array}$ & $\begin{array}{r}25 \\
20 \\
15 \\
10 \\
5\end{array}$ & $\begin{array}{l}35 \\
40 \\
45 \\
50 \\
55 \\
60\end{array}$ & $\begin{array}{l}40 \\
40 \\
40 \\
40 \\
40 \\
40\end{array}$ & $\begin{array}{r}4.998 \\
5.005 \\
\text { (b) } \\
\text { (b) } \\
\text { (b) }\end{array}$ & $\begin{array}{l}\text { 4. } 203 \\
\text { (b) } \\
\text { 4. } 198 \\
\text { 4. } 200 \\
\text { 4. } 195 \\
\text { 4. } 198\end{array}$ & (b) \\
\hline $\begin{array}{l}179 \\
181 \\
183\end{array}$ & $\begin{array}{l}35 \\
35 \\
35\end{array}$ & $\begin{array}{l}60 \\
55 \\
50\end{array}$ & $\begin{array}{r}5 \\
10 \\
15\end{array}$ & $\begin{array}{l}4.982 \\
\text { 4. } 992 \\
4.992\end{array}$ & $\begin{array}{l}\text { 4. } 204 \\
\text { 4. } 204 \\
\text { 4. } 204\end{array}$ &  \\
\hline $\begin{array}{l}117 \\
118 \\
119 \\
120 \\
121\end{array}$ & $\begin{array}{l}70 \\
65 \\
60 \\
55 \\
50\end{array}$ & $\begin{array}{l}25 \\
25 \\
25 \\
25 \\
25\end{array}$ & $\begin{array}{r}5 \\
10 \\
15 \\
20 \\
25\end{array}$ & $\begin{array}{l}4.986 \\
4.993 \\
5.005 \\
4.998 \\
5.005\end{array}$ & $\begin{array}{l}\text { (b) } \\
\text { (b) } \\
\text { (b) } \\
\text { (b) } \\
\text { (b) }\end{array}$ & . \\
\hline
\end{tabular}

a $a^{*}=\sqrt[3]{a^{2} c}$.

bPhase identified, but in an amount too small to permit a determination of the lattice parameter.

of $\mathrm{Be}_{2} \mathrm{C}$. UC reflections could be identified in the $\mathrm{X}$-ray patterns of all mixtures. The persistent occurrence of $\mathrm{UC}$, in these alloys, may reflect the need for still more rapid cooling to prevent the dissociation of $\mathrm{UC}_{2}$. The data indicate no solubility in the system $\mathrm{UC}_{2}-\mathrm{Be}_{2} \mathrm{C}$.

\section{d. Ternary Alloys in the System UC-UC ${ }_{2}-\mathrm{Be}_{2} \mathrm{C}$}

A limited number of ternary alloy preparations on three sections were reacted at $1,900^{\circ} \mathrm{C}$, and the data obtained are given in table 13. There appears to be little change in the parameters of either $\mathrm{UC}$ or $\mathrm{UC}_{2}$ in the alloys heated at $1,900^{\circ} \mathrm{C}$. All of the ternary alloys, however, do have somewhat larger $\mathrm{UC}_{\mathrm{ss}}$ parameter values than do those alloys consisting only of $\mathrm{UC}$ and $\mathrm{UC}_{2}$ (table 10 ).

The dissociation temperature of uranium sesquicarbide [9] is $1,800^{\circ} \mathrm{C}$, and therefore this phase does not appear in alloys reacted at $1,900^{\circ} \mathrm{C}$. Thus, the disappearing phase technique cannot be employed in the location of a three-phase region.

\subsection{Discussion of X-Ray Results}

The diffraction intensities, obtained by the X-ray Geiger counter method, for the carbides of uranium are, in general, rather weak. Although the X-ray patterns for cubic $\mathrm{UC}$ and $\mathrm{U}_{2} \mathrm{C}_{3}$ are sharp, the pattern for tetragonal $\mathrm{UC}_{2}$ is diffuse, making accurate parameter determinations difficult. All of the solid solutions formed in this system give comparatively weak intensities, the preparations increasingly distant from the pure compounds having increasingly poor patterns. These weak intensities are due, primarily, to the greater degree of disorder that is generally found in solid solutions.

Another difficulty encountered in the interpretation of the X-ray patterns is the inability to identify small amounts of $\mathrm{Be}_{2} \mathrm{C}$ in the presence of large amounts of any of the uranium carbides. This is due to the fact that beryllium is a much lighter element than uranium and has much less diffracting power. Free beryllium carbide cannot be recognized in the diffraction pattern in amounts less than about 25 to 35 mole percent. Therefore, the limits of solid solution must be found by changes in the slope of the parameters of the uranium-carbide component plotted against composition, as in figure 4. The disappearing phase method is of no value in locating the boundary between single-phase and two-phase areas where one of the phases is beryllium carbide.

Very heavy and very light atoms differ greatly in abilities to reflect and transmit X-rays. Because the uranium carbides are practically opaque to $\mathrm{X}$-rays, the X-ray beam is diffracted from the extreme surface of the X-ray spectrometer sample. In beryllium carbide, on the other hand, the X-ray beam may penetrate readily, and diffraction occurs throughout the whole thickness of the sample. This results in broadened peaks, the centers of which are slightly in error. When an X-ray sample is composed of a small amount of a heavy material, such as uranium monocarbide, and a large amount of a light material, such as beryllium carbide, the position of the UC diffraction peaks will be effectively displaced toward lower $2 \theta$ angles or larger $d$ values. The end result is to cause an error in the parameter measurement of the UC, which is a function of the amount of dilution with $\mathrm{Be}_{2} \mathrm{C}$. The slope of the $\mathrm{UC}_{\mathrm{ss}}$ parameter curve within the two-phase region (alloys 35 to 39 , table 11) can be partly attributed to this error of "dilution." 
$\mathrm{X}$-ray results indicate that $\mathrm{Be}_{2} \mathrm{C}$ enters into solid solution in UC to a considerable extent, resulting in an increase of the lattice parameter of the UC. As the bervllium atom has a much smaller radius than that of the uranium atom, this increase in parameter cannot be due to a substitution of Be for $\mathrm{U}$. The beryllium atom, however, is slightly larger than the carbon atom and could partially replace carbon in the interstitial sites between the uranium atoms in sixfold coordination. The only other available positions for the beryllium atoms in the UC structure are those of the empty sites comparable to those occupied by fluorine in the fluorite-type structure. The beryllium atoms occupy these latter positions in $\mathrm{Be}_{2} \mathrm{C}$, which has the antifluorite-type structure. It seems highly unlikely that the beryllium atom could occupy the same position in the UC solid solution that has the NaCl-type structure, where both the corners and the faces of the unit-cell are occupied by uranium atoms, with carbon atoms filling the interstices.

Equilibrium conditions seem to be very difficult to obtain in this system. Small amounts of $\mathrm{UC}_{2}$ were almost always indicated in the $\mathrm{X}$-ray patterns for samples that might be expected to consist of a single UC phase. The reason for this occurrence is not clear, but probably represents an unmixing reaction during quenching.

Uranium dicarbide has the same crystallographic structure as $\mathrm{CaC}_{2}$ and other alkaline-earth dicarbides, which all undergo a phase transformation to a cubic form at elevated temperatures [20]. These cubic forms are stable only at elevated temperatures. It is possible that $\mathrm{UC}_{2}$ also has a cubic form at some elevated temperature. The possibility of such a phase transformation might well be tested with hightemperature X-ray equipment.

\subsection{General Observation}

Suitable compacts were obtained by pressing finepowder mixtures at a pressure of 60,000 psi in hardened steel molds without binders. The specimens, so formed, were free from cracks and strong enough to permit handling. After the heat treatment at either $1,700^{\circ}$ or $1,900^{\circ} \mathrm{C}$, the pellets were hard and sound, even after the rather extreme thermal shock as a result of oil-quenching.

It was found that soaking in carbon tetrachloride was required to remove completely the quenching oil. This suggested the presence of some open pores in the heated specimens.

During the heating period the carbides were extremely sensitive to small amounts of oxygen in the furnace atmosphere. Crumbling of the pellet surface was an indication of oxygen contamination. Any oxygen contamination in the specimen was also shown by the presence of uranium-dioxide reflections in the X-ray pattern.

A comparison of the lattice parameters of the UC solid solutions in preparations heated in contact with graphite, molybdenum, or tantalum was made. The smaller parameters, which resulted from heating in contact with molybdenum or tantalum, indicated that reactions occurred for these combinations. For this reason, graphite cups were used to avoid reactions with the refractory metals.

\section{Summary}

Alloys within the system $\mathrm{UC}-\mathrm{UC}_{2}-\mathrm{Be}_{2} \mathrm{C}$ were prepared, heat-treated in the solid state in argon at $1,700^{\circ}$ and $1,900^{\circ} \mathrm{C}$, and analyzed by $\mathrm{X}$-ray methods to determine the crystalline phases present. The findings may be summarized as follows:

1. Uranium monocarbide forms single-phase alloys with as much as 20 mole percent of beryllium carbide at $1,700^{\circ} \mathrm{C}$, and approximately 40 mole percent at $1,900^{\circ} \mathrm{C}$.

2. Solid solutions of $\mathrm{Be}_{2} \mathrm{C}$ in UC have larger lattice parameters than either of the end members. It is believed that beryllium atoms partially replace the smaller carbon atoms of the UC structure.

3. Uranium monocarbide interacts with as much as 27 mole percent of uranium sesquicarbide (13.5 mole percent of uranium dicarbide) during the treatment at $1,700^{\circ} \mathrm{C}$ to form single-phase alloys.

4. Uranium dicarbide interacts with as much as 32 mole percent of uranium sesquicarbide (16 mole percent of uranium monocarbide) during the treatment at $1,700^{\circ} \mathrm{C}$ to form single-phase alloys.

5. No solubility of either the monocarbide or the dicarbide of uranium in uranium sesquicarbide is indicated.

6. The limitations of the X-ray methods prevent any definite statement about the interaction of $\mathrm{Be}_{2} \mathrm{C}$ and $\mathrm{UC}_{2}$.

7. Several possible explanations are offered with regard to the occurrence of $\mathrm{U}_{2} \mathrm{C}_{3}$ within a very restricted portion of the system.

8. The various interactions outlined above have shown no deleterious effects on the physical structure of the mixed carbide alloys. The preparations were hard and sound, even after the rather extreme thermal shock due to oil-quenching. In a like manner, the solid-solution alloys showed no improvement, insofar as was incidentally observed, in their stability to air and moisture over the individual pure carbides.

The continued interest and encouragement of R. F. Geller, Chief, Porcelain and Pottery Section of the National Bureau of Standards, and the assistance of Martha S. Richmond of the Analytical Chemistry Section is gratefully acknowledged.

Acknowledgment is made to the U. S. Atomic Energy Commission for their support of this investigation and for permission to publish these results.

The uranium-carbon alloys were obtained through the courtesy of Battelle Memorial Institute, and their cooperation is gratefully acknowledged. 


\section{References}

[1] H. Moissan, Study of uranium carbide, Compt. rend. 122, 247 (1896)

[2] P. Lebeau, The formula of uranium carbide, Compt. rend. 152, 955 (1911)

[3] O. Ruff and A. Heinzelmann, Uranium hexafluoride from uranium carbide and elementary fluorine with chlorine as catalyst, Z. anorg. u. allgem. Chem. 72,, 63 (1911).

[4] E. P. Polushkin, Alloys of iron and uranium, Iron Steel Inst. (London) Carnegie Schol. Mem. 10, 129 (1920).

[5] G. Hagg, Regularity in crystal structure of hydrides, borides, carbides and nitrides of the transition elements, Z. physik Chem. [B] 12, 33 (1931).

[6] R. E. Rundle, N. C. Baenzinger, A. S. Wilson, and R. A. MeDonald, The structure of the carbides, nitrides and oxides of uranium. J. Am. Chem. Soc. 70, 2, 99 (1948).

[7] L. M. Litz, A. B. Garrett, and F. C. Croxton, Preparation and structure of the carbides of uranium, J. Am. Chem. Soc. 70, 1718 (1948)

[8] H. A. Wilhelm, P. Chiotti, A. L. Snow, and A. H. Daane, The carbides of uranium and thorium, J. Am. Chem. Soc. Suppl. No. 2, 318 (1949)

[9] M. W. Mallett, A. F. Gerds, D. A. Vaughan, Uranium sesquicarbide, J. Electrochem. Soc. 98, 505 (1951).

[10] R. E. Rundle, A. S. Wilson, N. C. Baenzinger, and A. D. Tevebaugh, X-ray analysis of the uranium-carbon system, AECD-2325, Declassified.

[11] M. W. Mallett, A. F. Gerds, and H. R. Nelson, The uranium-carbon system, BMI-63, Declassified.
[12] P. Lebeau, On a carbide of beryllium, Compt, rend, 121, 496 (1895)

[13] M. V. Stackelberg and F. Quatrum, The structure of beryllium carbide, Z. Physik Chem. 27, 50 (1934).

[14] J. Kielland and L. Tronstad, The production of anhydrous beryllium chloride from beryllium oxide via beryllium carbide, Kgl. Norske Videnskab. Selskabs, Forh, 8, 147 (1935) (published in 1936); C. A. 30, 72885 (1936).

[15] C. J. Rodden, Analytical chemistry of the manhattan project, p. 33 (McGraw-Hill Book Co., Inc., New York, N. Y., 1950).

[16] W. F. Hillebrand, G. E. F. Lundell, H. A. Bright, and J. I. Hoffman, Applied inorganic analysis, p. 133 (John Wiley \& Sons, Inc., New York, N. Y., 1953).

[17] M. H. Fletcher, C. E. White, and M. S. Sheftel, Determination of beryllium in ores, Ind. Eng. Chem., Anal Ed. 18, 179 (1946).

[18] E. B. Sandell, Colorimetric metal analysis, p. 271 (Interscience Publishers, Incorporated, New York, N. Y., 1944).

[19] C. J. Rodden and J. J. Tregonning private communication).

[20] M. A. Bredig, J. Phys. Chem. 46, 801 (1942).

[21] W. J. Youden, Statistical methods for chemists, p. 12 (John Wiley \& Sons, New York, N. Y. 1951).

WAshington, July 1, 1954. 